\title{
Contrasting physical properties of black carbon in urban Beijing between winter and summer
}

\author{
Dantong Liu ${ }^{1,2}$, Rutambhara Joshi ${ }^{2,5}$, Junfeng Wang ${ }^{4}$, Chenjie Yu ${ }^{2}$, James D. Allan ${ }^{2,5}$, Hugh Coe ${ }^{2}$, Michael J. Flynn ${ }^{2}$, \\ Conghui Xie ${ }^{3}$, James Lee ${ }^{6}$, Freya Squires ${ }^{6}$, Simone Kotthaus ${ }^{7}$, Sue Grimmond ${ }^{7}$, Xinlei Ge ${ }^{4}$, Yele Sun ${ }^{3}$, and \\ Pingqing $\mathrm{Fu}^{3}$ \\ ${ }^{1}$ Department of Atmospheric Sciences, School of Earth Sciences, Zhejiang University, Hangzhou, Zhejiang, China \\ ${ }^{2}$ Centre for Atmospheric Sciences, School of Earth and Environmental Sciences, University of Manchester, Manchester, UK \\ ${ }^{3}$ Institute of Atmospheric Physics, Chinese Academy of Sciences, Beijing, China \\ ${ }^{4}$ School of Environmental Science and Engineering, Nanjing University of Information Science and Technology, \\ Nanjing, China \\ ${ }^{5}$ National Centre for Atmospheric Science, University of Manchester, Manchester, UK \\ ${ }^{6}$ Department of Chemistry and National Centre for Atmospheric Science, University of York, York, UK \\ ${ }^{7}$ Department of Meteorology, University of Reading, UK
}

Correspondence: Dantong Liu (dantongliu@zju.edu.cn)

Received: 28 October 2018 - Discussion started: 15 November 2018

Revised: 29 April 2019 - Accepted: 2 May 2019 - Published: 21 May 2019

\begin{abstract}
Black carbon (BC) is known to have major impacts on both human health and climate. The populated megacity represents the most complex anthropogenic BC emissions where the sources and related impacts are very uncertain. This study provides source attribution and characterization of $\mathrm{BC}$ in the Beijing urban environment during the joint UK-China APHH (Air Pollution and Human Health) project, in both winter (November-December 2016) and summer (May-June 2017). The size-resolved mixing state of BCcontaining particles was characterized by a single-particle soot photometer (SP2) and their mass spectra was measured by a soot particle aerosol mass spectrometer (SP-AMS). The refractory $\mathrm{BC}$ (rBC) mass loading was around a factor of 2 higher in winter relative to summer, and more variable coatings were present, likely as a result of additional surface emissions from the residential sector and favourable condensation in the cold season. The characteristics of the BC were relatively independent of air mass direction in summer, whereas in winter air masses from the Northern Plateau were considerably cleaner and contained less-coated and smaller $\mathrm{BC}$, but the BC from the Southern Plateau had the largest core size and coatings.

We compare two online source apportionment methods using simultaneous measurements made by the SP2, which
\end{abstract}

measures physical properties of $\mathrm{BC}$, and the chemical approach using the positive matrix factorization (PMF) of mass spectra from the SP-AMS for the first time. A method is proposed to isolate the $\mathrm{BC}$ from the transportation sector using a mode of small BC particles (core diameter $D_{\mathrm{c}}<$ $0.18 \mu \mathrm{m}$ and coating thickness $\mathrm{ct}<50 \mathrm{~nm}$ ). This mode of BC highly correlated with $\mathrm{NO}_{x}$ concentration in both seasons $(\sim$

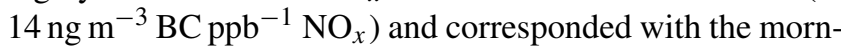
ing traffic rush hour, contributing about $30 \%$ and $40 \%$ of the total $\mathrm{rBC}$ mass (35\% and $55 \%$ in number) in winter and summer respectively. The BC from coal burning or biomass burning was characterized by moderate coatings ( $\mathrm{ct}=50$ $200 \mathrm{~nm}$ ) contributing $\sim 20 \%-25 \%$ of rBC mass. Large uncoated BC particles $\left(D_{\mathrm{c}}>0.18 \mu \mathrm{m}\right.$ and $\left.\mathrm{ct}<50 \mathrm{~nm}\right)$ were more likely to be contributed by coal combustion, as these particles were not present in urban London. This mode was present in Beijing in both winter ( $\sim 30 \%-40 \%$ rBC mass $)$ and summer ( $\sim 40 \%$ rBC mass) but may be dominated by the residential and industrial sector respectively. The contribution of $\mathrm{BC}$ thickly coated with secondary species (ct $>200 \mathrm{~nm}$ ) to the total $\mathrm{rBC}$ mass increased with pollution level in winter but was minor in summer. These large BC particles importantly enhanced the absorption efficiency at high pollution levels - in winter when $\mathrm{PM}_{1}>100 \mu \mathrm{g} \mathrm{m}^{-3}$ 
or $\mathrm{BC}>2 \mu \mathrm{g} \mathrm{m}^{-3}$, the absorption efficiency of BC increased by $25 \%-70 \%$. The reduction of emissions of these large $\mathrm{BC}$ particles and the precursors of the associated secondary coating will be an effective way of mitigating the heating effect of $\mathrm{BC}$ in urban environments.

\section{Introduction}

Black carbon aerosol (BC) has a significant impact on both climate (Bond et al., 2013) and human health (Baumgartner et al., 2014). Its regional impact in the atmosphere may be very large, especially close to polluted hotspots such as in South and East Asia, where anthropogenic emissions are high and population exposure is severe (Ramanathan and Carmichael, 2008). It has been estimated that BC over China could contribute up to $14 \%$ of the global radiative forcing budget (Li et al., 2016). Reducing BC has been postulated as a win-win policy intervention because of the shorter atmospheric lifetime of BC compared to the greenhouse gases, delivering immediate mitigation while at the same time improving air quality (Kopp and Mauzerall, 2010).

Beijing, as one of the most populated megacities in the world, has experienced severe air pollution (Yang et al., 2005; Xu et al., 1994). The complexity of emissions from multiple sectors that are often co-located (Li et al., 2017) make it extremely challenging to attribute source contributions to the BC load, hindering policy making on emission regulations. The source apportionment of BC in urban environments has been studied using both online and offline measurements and using site receptor models (Cao et al., 2005; Viana et al., 2008, and references therein). Most of the techniques separate the fossil fuel BC, such as separate traffic sources from the solid fuel burning fraction such as that from wood burning (Sandradewi et al., 2008; Healy et al., 2012) or open biomass burning (Schwarz et al., 2008). These techniques include using biomass burning tracers in aerosol (Puxbaum et al., 2007) or using individual organic tracer compounds to attribute the sources and provide time series representing the different sources. These are then used to segregate the different $\mathrm{BC}$ emission contributions by multilinear regression (Liu et al., 2011; Laborde et al., 2013). An approach using Aethalometer measurements has been widely used based on the spectral dependence of absorption (Sandradewi et al., 2008). This technique needs to assume a prescribed absorption spectrum from traffic or wood burning sources which may be subject to variation under different burning conditions (Zotter et al., 2017). Isotope analysis of elemental carbon, in conjunction with thermal separation, allows identification of modern carbon (e.g. from biomass) from fossil fuel (from diesel or coal) based on the ${ }^{14} \mathrm{C}$ abundance (Bernardoni et al., 2013; Zhang et al., 2012). This method has been considered to be relatively unambiguous in isolating wood burning sources from traffic sources and has been used to validate the other methods in attributing elemental carbon (Liu et al., 2013; Zotter et al., 2017).

These techniques mostly use distinct features in the chemistry or physical properties to isolate one BC source from the other, and to do so requires that there are unique characteristics that are separable. The BC sources in Beijing are combinations of residential, industrial and transport sectors (Li et al., 2017), and the fuel use could be rather more complex than two distinct sources on which most techniques are based. For example, both coal burning and diesel fuel could emit fossil fuel BC, which may not be isolated through isotope analysis, and also the absorption spectrum of $\mathrm{BC}$ from different sources may vary considerably, and to assume a single pattern based on Aethalometer measurements may not be suitable to attribute multiple sources. The fast secondary processing of aerosols in Beijing (Sun et al., 2016b) may make the source attribution of primary BC even more challenging as the secondary coating formed on BC may alter its original source-dependent features. Given these difficulties it is unlikely that any single methodology will give unambiguous results, but a combination of different methods may improve the understanding on the source attribution because sourcespecific physiochemical properties of BC may be reflected in different ways by different methods.

It is also necessary to gain knowledge on the microphysical structure and mixing state of the soot, namely its size and what other materials are present on the individual particles, as these dictate its impact on the wider atmosphere. Other material present on a BC particle (a coating) may alter its optical properties (Liu et al., 2017), affecting the direct radiative effect on the local atmosphere, and it may also make it more susceptible to in-cloud scavenging, meaning that it can perturb the cloud properties or experience a shortened atmospheric lifetime through wet deposition (Hodnebrog et al., 2014). The source profile of the size-resolved mixing state of $\mathrm{BC}$ is desired for the evaluation of $\mathrm{BC}$ properties in process models (Riemer et al., 2009), especially for environments with combined sources (Fierce et al., 2016).

This study quantifies the source attribution of BCcontaining particles in urban Beijing and delivers sourcespecific information on their properties by combining two techniques, both of which directly characterize BCcontaining particles but are based on physical and chemical techniques respectively. The physical technique uses a single-particle soot photometer (DMT, SP2), which was previously used for source apportionment of BC in urban London (Liu et al., 2014). This approach is to examine the mixing state of BC particles as a function of their core size, and this has been used to attribute the $\mathrm{BC}$ from traffic diesel and wood burning source. The chemical approach uses the soot particle aerosol mass spectrometer (Aerodyne, SP-AMS) which has been previously used to identify the chemical compositions of coatings associated with BC (Onasch et al., 2012a), which may be used to determine primary sources or secondary processing of $\mathrm{BC}$. The combination of both techniques in this 
study will give the detailed physiochemical properties of $\mathrm{BC}$ influenced by mixed sources. In particular, by combining the approaches the contribution of different emission sources to the optical properties of $\mathrm{BC}$ can be quantified and so an attribution of different sources to the BC heating in the atmospheric column can be made.

\section{The site, meteorology and air mass classification}

The experiments were conducted at the tower site of the Institute of Atmospheric Physics (IAP), Chinese Academy of Sciences $\left(39^{\circ} 58^{\prime} 28^{\circ} \mathrm{N}, 116^{\circ} 22^{\prime} 16^{\circ} \mathrm{E}\right)$, in Beijing during both winter (November-December 2016) and summer (May-June 2017) periods, as part of the Air Pollution and Human Health-Beijing campaign. This site represents the typical urban Beijing environment with pollution influences from surrounding traffic, commercial activities, residential activities such as cooking and home heating, and regional transport (Sun et al., 2016a).

Figure 1a shows the terrain of the North China Plain (NCP) region to the north of Beijing, and Fig. $1 \mathrm{~b}$ shows the surface emission inventory of BC for the year 2010 (Li et al., 2017). The high anthropogenic BC emission can be generally divided by the border along the Taihang and Yan (Yanshan) mountain ridges, beyond which the region from north-west Beijing has relatively lower emissions. Considerably higher emissions are also present across the Southern Plateau region. In order to investigate the regional influence of pollutants in Beijing, the regions over the NCP and the plateau are classified according to the terrain and $\mathrm{BC}$ surface emission, shown in Fig. 1c. The regions are firstly classified as the plateau and plain according to the terrain height below and above $800 \mathrm{~m}$, and then for the region $<800 \mathrm{~m}, 116.5^{\circ} \mathrm{E}$ (the longitude of central Beijing) is used to separate the Eastern and Western NCP (E and W are used as the abbreviations during the following discussion); the region $>800 \mathrm{~m}$ is separated as the Northern and Southern Plateau (N and S are used as abbreviations for the following discussion) using the border along $41.5^{\circ} \mathrm{N}$; the ocean is defined as the terrain height below zero. The Northern Plateau has significantly lower emission, meaning north-westerly air masses will bring clean air into Beijing and are likely to reduce pollution levels in the city, whereas westerlies may bring pollutants from the Southern Plateau and south-westerlies could transport the high emissions from central China to the NCP. The local area is defined in this work as the area within the square $\pm 0.25^{\circ}$ away from the measurement site. BC emission inventories from different sectors are shown in Fig. S1 in the Supplement. In winter the residential sector, which is mainly composed of residential coal burning, contributes the vast majority of $\mathrm{BC}$ emissions; whereas the emissions from the industrial (which also contains significant coal consumption) and transportation sectors are maintained throughout the year. This means the differences in $\mathrm{BC}$ emissions be- tween winter and summer will mainly result from changes in the residential sector.

The HYSPLIT back-trajectory model (Draxler and Hess, 1998) was run using the $1^{\circ} \times 1^{\circ}$ horizontal and vertical wind fields provided by the GDAS1 reanalysis meteorology. Given that the emissions are intensive around the immediate Beijing area, air mass back trajectories were only followed for the previous $24 \mathrm{~h}$ to examine the influence from the most recent air masses. The back trajectories are then mapped onto the classified regions (Fig. 1c) to investigate variations in the potential regional source influence. The back trajectories have a $1 \mathrm{~h}$ time resolution and each point along a single $24 \mathrm{~h}$ trajectory is assigned to one of the four regional classifications. All the points along a single trajectory are then used to determine the fraction of time during the previous day that the air mass spent above each of the classified regions as shown in the bottom panel of Fig. 3a and b. This method has been applied previously in the western Africa region to identify the potential source contributions (Liu et al., 2018). Note that the HYSPLIT analysis is not able to reproduce the dispersion of the air mass, but such effects are likely to be minimal since the trajectories are only investigated over the previous $24 \mathrm{~h}$.

Each back trajectory is assigned to be predominately from one of the regions based on a ranked classification scheme that takes account of the likely greater influence on the pollution at the receptor from closer regions with large emissions. The methodology considers each region in turn, beginning with the Western NCP air mass because it represents the mostly polluted region, and a relatively lower air mass fraction of the Western NCP will make an important contribution to the pollutants measured at the receptor. If the back trajectory spent more than $10 \%$ of the previous $24 \mathrm{~h}$ over the Western NCP, it was classified as being from that sector. The $10 \%$ threshold was somewhat arbitrarily set based on an iteration over a range of values - too low a threshold biased air masses towards the very near field, whereas too high a value failed to classify a large fraction of air masses. The sensitivity of the threshold was tested by varying it between $9 \%$ and $11 \%( \pm 10 \%)$, and the classification was shown to be insensitive to change. The following regions are then considered in a similar way in turn based on the following order: Eastern NCP, Southern Plateau and Northern Plateau, with each above $10 \%$ air mass fraction. Lastly if the air mass spent more than $20 \%$ in the local area it is defined as having significant local influence.

The meteorological parameters such as wind, relative humidity $(\mathrm{RH})$ and temperature were measured at ground level $(z=10 \mathrm{~m})$ and also on the tower at $z=120 \mathrm{~m}$. The temperature and RH at $z=10 \mathrm{~m}$ are used, but the wind at $120 \mathrm{~m}$ is used to avoid the surface friction effect. In addition, the planetary boundary layer height (PBLH) spanning the experimental period was determined using lidar and ceilometer measurements (Kotthaus and Grimmond, 2018). 
(a)

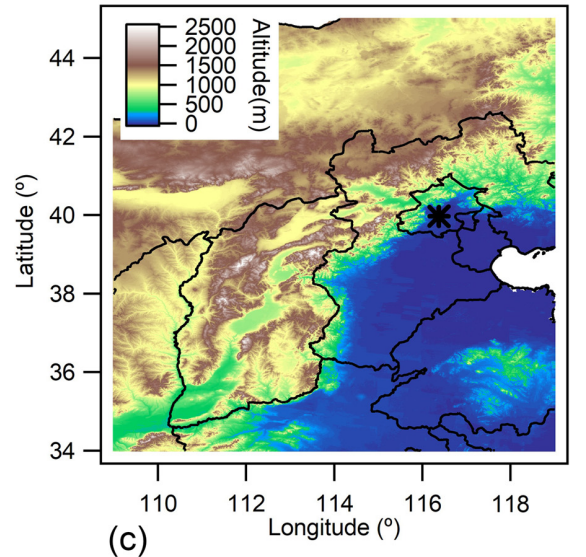

(c)

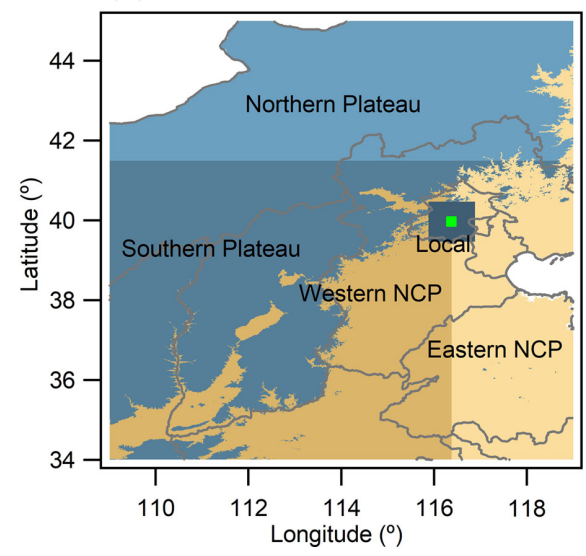

(b)

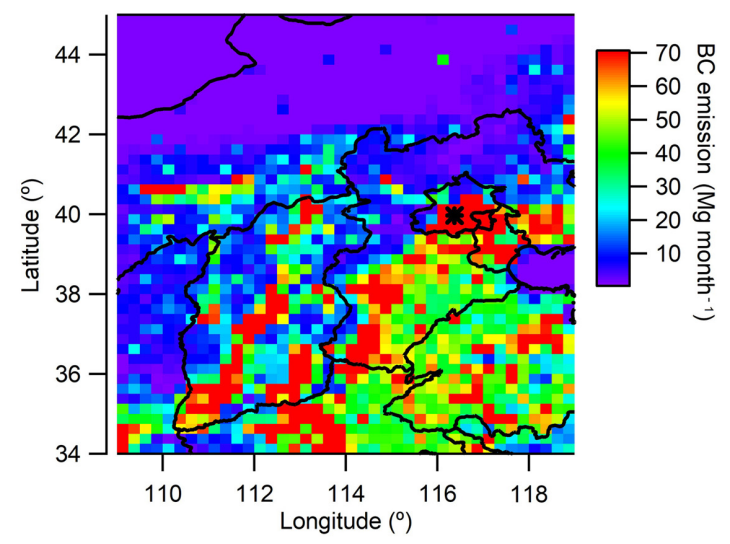

Figure 1. (a) Terrain height for the North China Plain (NCP) and the plateau; (b) BC emissions from all sectors in 2010; (c) the regional classification according to terrain height and emission.

\section{Instrumentation and data analysis}

\subsection{The physical properties of $\mathrm{BC}$}

The physical properties of individual refractory BC particles were characterized using a single-particle soot photometer (SP2) manufactured by DMT Inc. (Boulder, CO, USA). The instrument operation and data interpretation procedures are described elsewhere (Liu et al., 2010; McMeeking et al., 2010). The SP2 incandescence signal was calibrated for refractory $\mathrm{BC}(\mathrm{rBC})$ mass using Aquadag ${ }^{\circledR}$ black carbon particle standards (Aqueous Deflocculated Acheson Graphite, manufactured by Acheson Inc., USA) and corrected for ambient $\mathrm{rBC}$ with a factor of 0.75 (Laborde et al., 2012). The mass-equivalent diameter of the $\mathrm{rBC}$ core $\left(D_{\mathrm{c}}\right)$ is obtained from the measured $\mathrm{rBC}$ mass assuming a density of $1.8 \mathrm{~g} \mathrm{~cm}^{-3}$ (Bond and Bergstrom, 2006). For a given time window, the mass median diameter (MMD) of the $\mathrm{rBC}$ core is calculated from the $D_{\mathrm{c}}$ distribution below and above which the $\mathrm{rBC}$ mass was equal.

The scattering signal of each $\mathrm{BC}$ particle measured by the SP2 is determined using a leading edge only (LEO) technique to reconstruct the distorted scattering signal when the particle passes through the SP2 laser beam (Gao et al., 2007). This was used to determine the scattering enhancement $\left(E_{\mathrm{sca}}\right)$ for each single particle which is defined as the ratio between the measured scattering intensity resulting from the entire BC-containing particle, including any coating, and the calculated scattering intensity resulting from the uncoated BC core of that particle (Liu et al., 2014; Taylor et al., 2015), expressed as

$E_{\text {sca }}=\frac{S_{\text {measured,coated BC }}}{S_{\text {calculated,uncoated BC }}}$,

where the numerator is the scattered light intensity of the coated BC particle measured by the SP2, and the denominator is the calculated scattering intensity of the uncoated $\mathrm{BC}$ core based on the measured mass and using a refractive index of BC 2.26+1.26i at the SP2 laser wavelength, $\lambda=1064 \mathrm{~nm}$ (Moteki et al., 2010). For a given $D_{\mathrm{c}}$, a higher $E_{\mathrm{sca}}$ means a thicker coating and $E_{\text {sca }}=1$ means there is no coating. The coated $\mathrm{BC}$ particle size $\left(D_{\mathrm{p}}\right)$ is then determined by matching the modelled scattering with the measured scattering by applying a Mie core-shell lookup table (Taylor et al., 2015). For the current SP2 configuration (Liu et al., 2017), the detection efficiency for the coating, taking into account only 


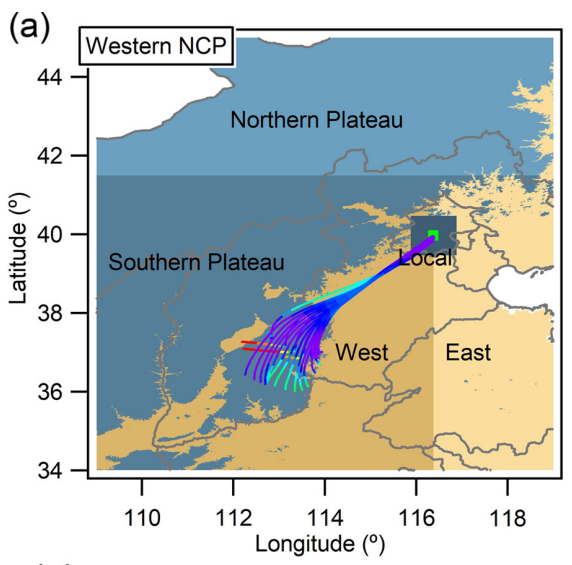

(c)

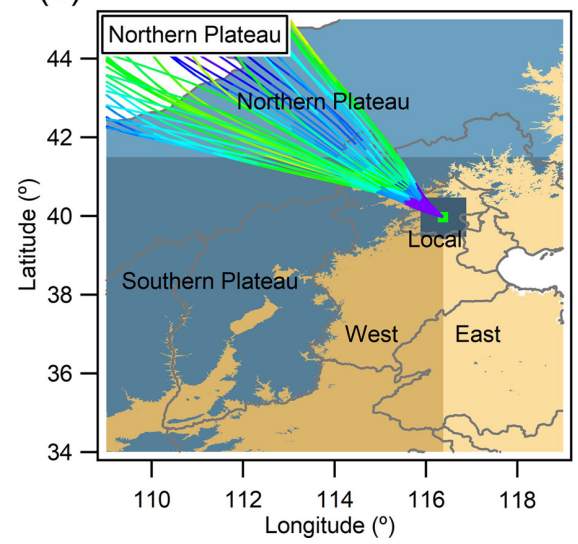

(b)

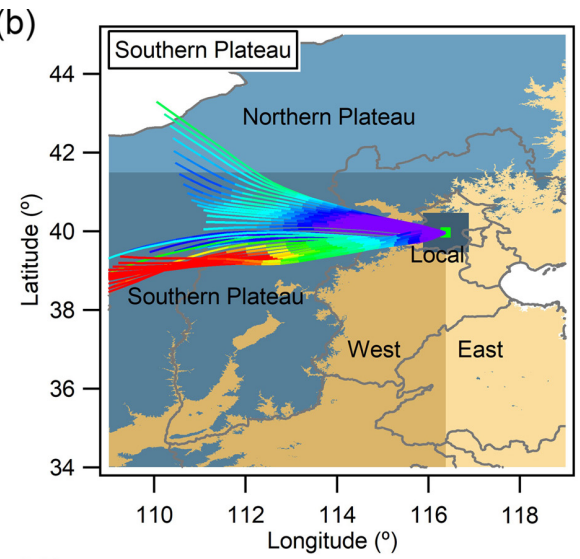

(d)

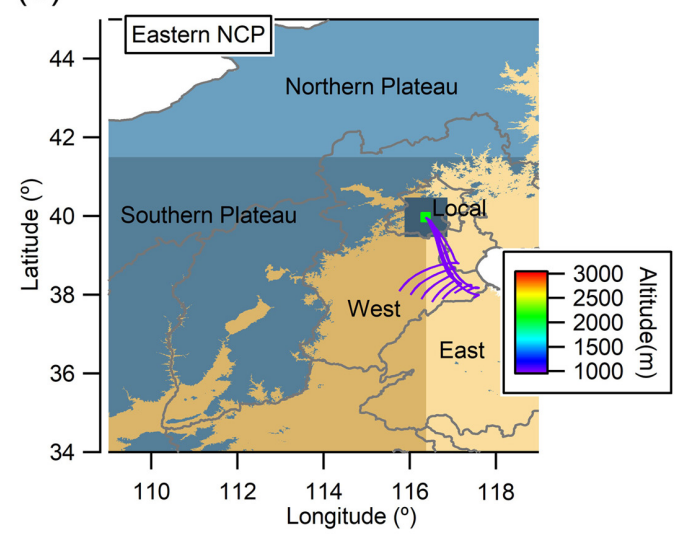

Figure 2. Classified air mass origins based on back-trajectory analysis: Western NCP, Southern Plateau, Northern Plateau and Eastern NCP.

particles with sufficient signal to noise in the two-element APD (avalanche photodiode) detector signal to perform reliable LEO fitting, is $>80 \%$ for $D_{\mathrm{c}}=0.12-0.45 \mu \mathrm{m},>60 \%$ for $D_{\mathrm{c}}>0.45 \mu \mathrm{m}$ (due to partly saturated signal) and $>50 \%$ for $D_{\mathrm{c}}=0.08-0.12 \mu \mathrm{m}$.

The bulk relative coating thickness $\left(D_{\mathrm{p}} / D_{\mathrm{c}}\right)$ in a given time window is calculated as the total volume of coated $\mathrm{BC}$ particles divided by the total volume of the rBC cores (Liu et al., 2014), expressed as

$\frac{D_{\mathrm{p}}}{D_{\mathrm{c}}}=\sqrt[3]{\frac{\sum_{i} D_{\mathrm{p}, i}^{3}}{\sum_{i} D_{\mathrm{c}, i}^{3}}}$,

where $D_{\mathrm{p}, i}$ and $D_{\mathrm{c}, i}$ are the coated and $\mathrm{rBC}$ diameters for each single particle respectively (the abbreviations using subscript $i$ refer to the single particle; variables without a subscript refer to the bulk information). Note that the bulk $D_{\mathrm{p}} / D_{\mathrm{c}}$ is largely independent of the uncertainties arising from smaller particles because of their less important contribution to the integrated volume.

The volume-weighted coated BC size $\left(D_{\mathrm{p}, \mathrm{v}}\right)$ is then calculated as the product of the bulk relative coating thickness and the MMD of the $\mathrm{BC}$ cores, to indicate the mean coated $\mathrm{BC}$ size (Eq. 3). The bulk mixing ratio of coating mass over rBC mass $\left(M_{\mathrm{R}, \text { bulk }}\right)$ can be also derived from $D_{\mathrm{p}} / D_{\mathrm{c}}$ assuming densities for the bulk coating and $\mathrm{rBC}$ core (Eq. 4):

$$
\begin{aligned}
& D_{\mathrm{p}, \mathrm{v}}=\frac{D_{\mathrm{p}}}{D_{\mathrm{c}}} \times \mathrm{MMD}, \\
& M_{\mathrm{R}, \text { bulk }}=\left(\left(\frac{D_{\mathrm{p}}}{D_{\mathrm{c}}}\right)^{3}-1\right) \times \frac{\rho_{\text {coating }}}{\rho_{\mathrm{rBC}}} .
\end{aligned}
$$

The mass absorption cross section at $\lambda=550 \mathrm{~nm}\left(\mathrm{MAC}_{550}\right)$ is calculated for each single particle by assuming the refractive index of $\mathrm{rBC}$ core $1.95+0.79 i$ (Bond and Bergstrom, 2006) and coating refractive index 1.50+0i (Liu et al., 2015), using the Mie core-shell approach (Bohren and Huffman, 2008). Note that the absorption enhancement due to coating is considered to only occur when the coating mass over rBC mass is larger than 3 according to the recent study of (Liu et al., 2017), and the coating here is assumed to be nonabsorbing. Figure $\mathrm{S} 3$ gives the calculated $\mathrm{MAC}_{550}$ mapped on the $E_{\text {sca }}-D_{\text {c }}$ plot. The $\mathrm{MAC}_{550}$ in bulk for a given time window is calculated as the integrated absorption coefficient $\left(\mathrm{MAC} \times m_{\mathrm{rBC}}\right)$ for all particles divided by the integrated par- 
(a)
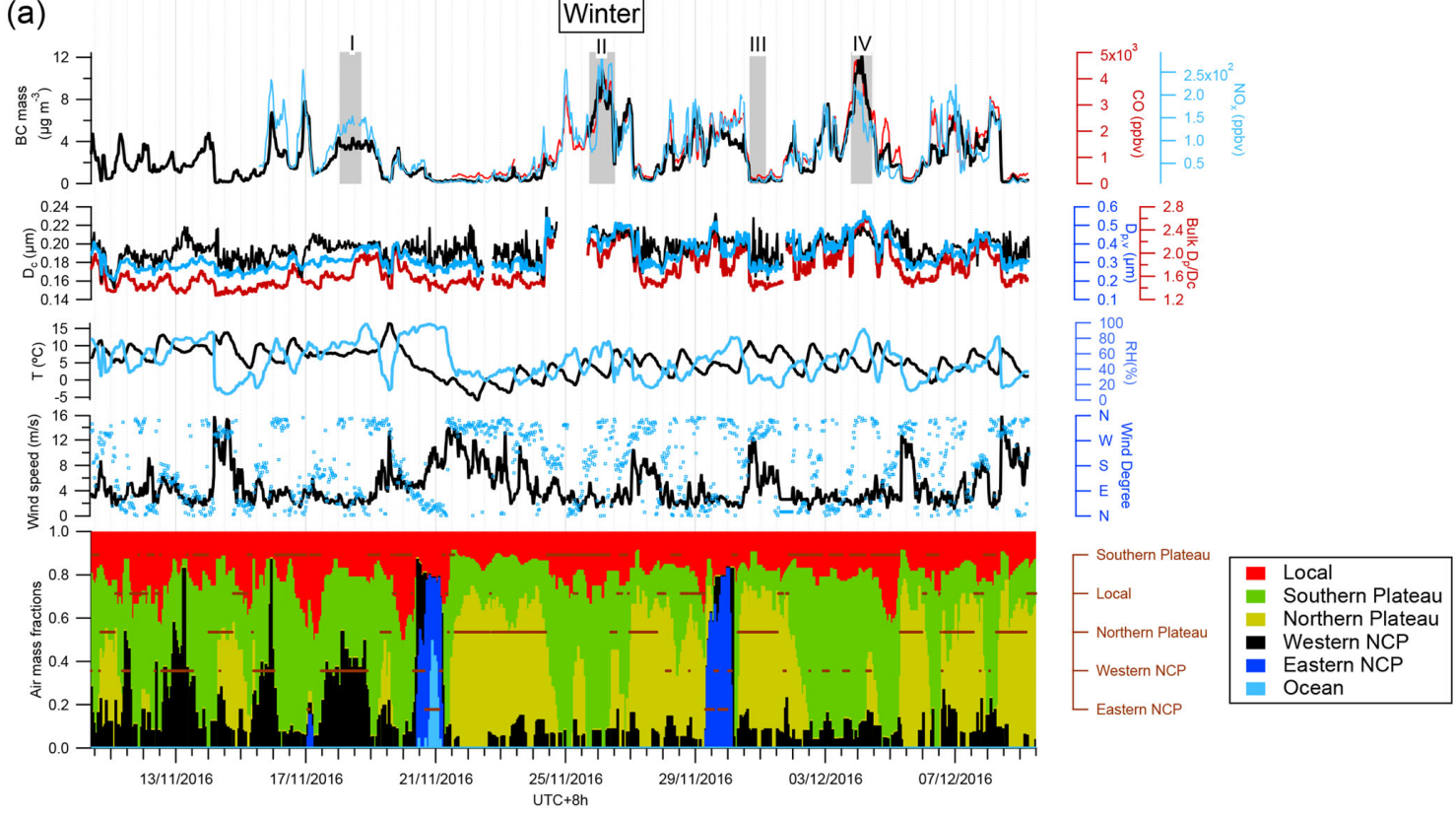

(b)
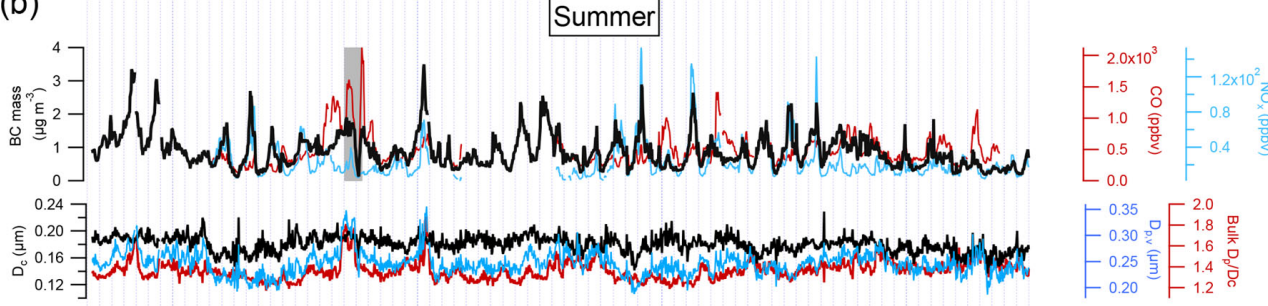

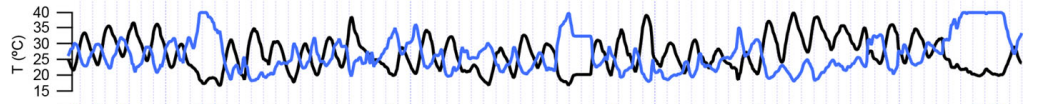
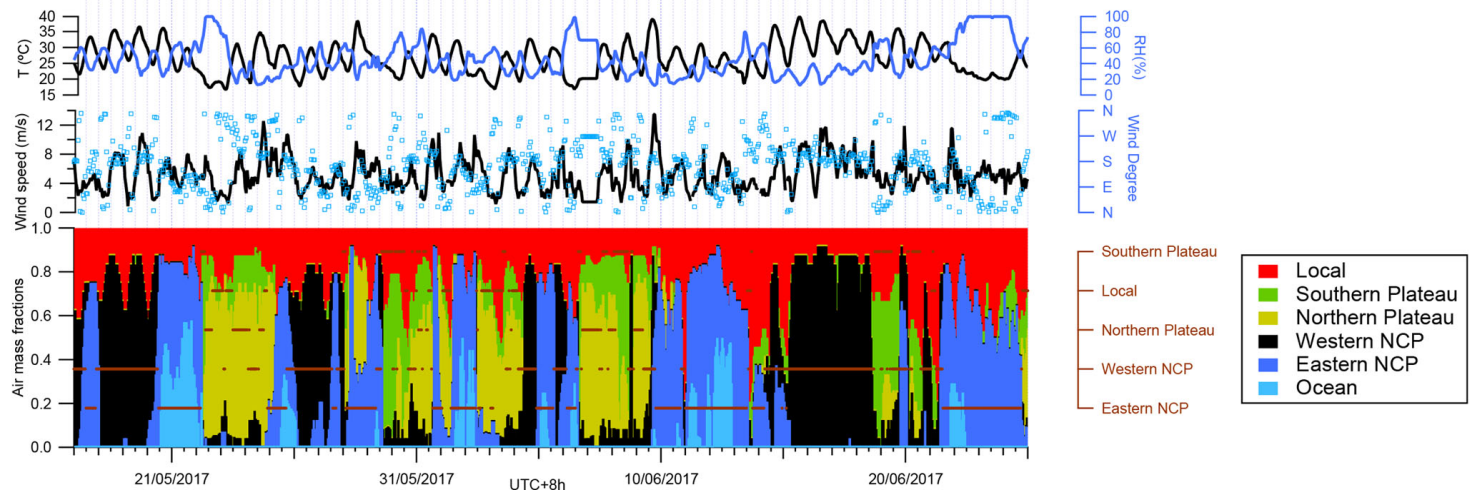

Figure 3. Time series of $\mathrm{BC}$-related properties in the winter (a) and summer (b) experiments. From top to bottom subpanels: $\mathrm{BC}$ mass loading, $\mathrm{CO}$ and $\mathrm{NO}_{x} ; \mathrm{BC}$ bulk $D_{\mathrm{p}} / D_{\mathrm{c}}$, core mass median diameter (MMD) and coated volume-equivalent diameter; ambient temperature and RH at $z=8 \mathrm{~m}$; wind speed and direction at $z=120 \mathrm{~m}$; air mass fractions from different origins based on back-trajectory analysis, with the brown horizontal lines indicating the classified air mass types. The vertical grey shades mark the periods for the detailed mixing state analysis in Fig. 9. 
ticle masses, expressed by Eq. (5):

$\mathrm{MAC}=\frac{\sum_{i} \mathrm{MAC}_{i} \times m_{\mathrm{rBC}, i}}{\sum_{i} m_{\mathrm{rBC}, i}}$,

where $\mathrm{MAC}_{i}$ and $m_{\mathrm{rBC}, i}$ are the MAC and $\mathrm{rBC}$ mass for each single particle respectively. This calculation is performed for each type of BC.

A Photoacoustic Extinctiometer (PAX; Droplet Measurement Technologies, Boulder, CO, USA) (Wang et al., 2014; Selimovic et al., 2018) was deployed to directly measure the in situ aerosol light absorption every minute using photoacoustic technology. The light-absorbing particles are heated by a laser in the acoustic chamber, and this heating produces pressure waves which are detected by a microphone. The calibration of scattering and absorption for PAX was performed using the polystyrene latex spheres and fullerene soot respectively. The absorption coefficient at $\lambda=870 \mathrm{~nm}\left(\sigma_{\mathrm{abs}, 870}\right)$ is measured by the PAX. The mass absorption cross section (MAC) is determined as the absorption coefficient per unit rBC mass. Note that in this study $\sigma_{\mathrm{abs}, 870}$ values for $\mathrm{rBC}$ mass loadings $<0.5 \mu \mathrm{g} \mathrm{m}^{-3}$ were not used for MAC calculations due to the large uncertainty of absorption measurement at low concentration.

\subsection{BC chemical composition}

The chemical composition of black-carbon-containing particles, including the refractory $\mathrm{BC}$ and coating compositions, is measured by a soot particle mass spectrometer (SPAMS) (Onasch et al., 2012a; Wang et al., 2017). The results from SP-AMS measurement during the APHH (Air Pollution and Human Health) project are detailed in Wang et al. (2019). The SP-AMS was run in laser-only mode and so only detected compositions for BC-containing particles. In this mode the non-refractory components were not detected if they were not contained within a $\mathrm{BC}$ particle. The ionization efficiency (IE) and relative ionization efficiency (RIE) of sulfate and nitrate were calibrated by using ammonium nitrate and ammonium sulfate (Jayne et al., 2000). RIE of rBC was calibrated by using Regal Black (RB, REGAL 400R pigment black, Cabot Corp.) (Onasch et al., 2012b). Positive matrix factorization (PMF) (Paatero and Tapper, 1994) was applied to the mass spectra of the organic and $\mathrm{rBC}$ components to attribute the source contribution of $\mathrm{BC}$-containing particle mass, as detailed in Wang et al. (2019). Four types of BCcontaining particles associated with different organic coatings were identified: fossil fuel combustion organic aerosol (FOA), biomass burning OA (BBOA), low-volatility organics (OOA1) and semi-volatile organics (OOA2). In addition, a polycyclic aromatic hydrocarbon (PAH) factor was also derived from the SP-AMS measurement, which is associated with coal combustion (Sun et al., 2016a).

\section{Results}

\subsection{Overview of BC physical properties}

The following section describes the measured $\mathrm{BC}$ properties in both the winter and the summer seasons. Each property is discussed in turn and the similarities and differences between the seasons highlighted to clearly identify property changes that can be linked to changes in sources or processes in summer and winter.

Figure 3 shows the temporal variation of the physical properties of BC, associated gaseous pollutants, and meteorological parameters and their association with the air mass classifications. As the bottom panels show, the site was mostly influenced by northerly and westerly air masses in winter, and very few air masses came from the Eastern NCP. The first half of the winter campaign up to 20 November was periodically influenced by air masses from the Western NCP, and during the second half the synoptic meteorology shifted appreciably and was dominated by northerly (from the Northern Plateau) or westerly (from the Southern Plateau) air masses, with the period between 2 and 4 December dominated by air from the Southern Plateau. The temperature dropped from $\sim 10^{\circ} \mathrm{C}$ to below $5^{\circ} \mathrm{C}$ when the air mass type shifted to deliver air from the plateau. In summer, Beijing received air from the Western NCP, the Eastern NCP and the Northern Plateau, with southerly air masses more dominant than those from the north.

The classified air mass types are generally consistent with the local wind directions measured at $120 \mathrm{~m}$ for both seasons (Fig. 4). In winter, the Northern Plateau air masses were characterised by high speed and dry NW winds; in summer the flow was not as strong. Air masses from the Southern Plateau were associated with both northerly and southerly winds but with much lower wind speed and systematically higher $\mathrm{RH}$ than the Northern Plateau air masses. The south-westerly air masses also had the highest RH, which is consistent with previous observations that show air masses from lower latitudes contained more moisture in wintertime (Tao et al., 2012). In summer, air masses from the Western NCP showed lower RH. The site showed lower wind speed and wider variation of RH when influenced by local air masses.

$\mathrm{BC}$ properties associated with different air mass types in both the winter and summer seasons are compared in Fig. 5. rBC mass loadings were higher in winter than in summer by around a factor of 2 for both local and regionally transported air masses, mostly likely due to a combination of higher surface emissions from both the local Beijing region and the surrounding area in the cold season, as well as the increased frequency of lower boundary layer heights in winter (Sect. 4.4). However, air masses from the Northern Plateau during periods of strong and dry wind had a notable effect on the rBC mass in winter, greatly reducing the $\mathrm{rBC}$ mass in Beijing. This air mass type contributed to over $90 \%$ of the cleaner days ( $\mathrm{rBC}$ mass concentration $<1 \mu \mathrm{g} \mathrm{m}^{-3}$ ) in winter. This is 

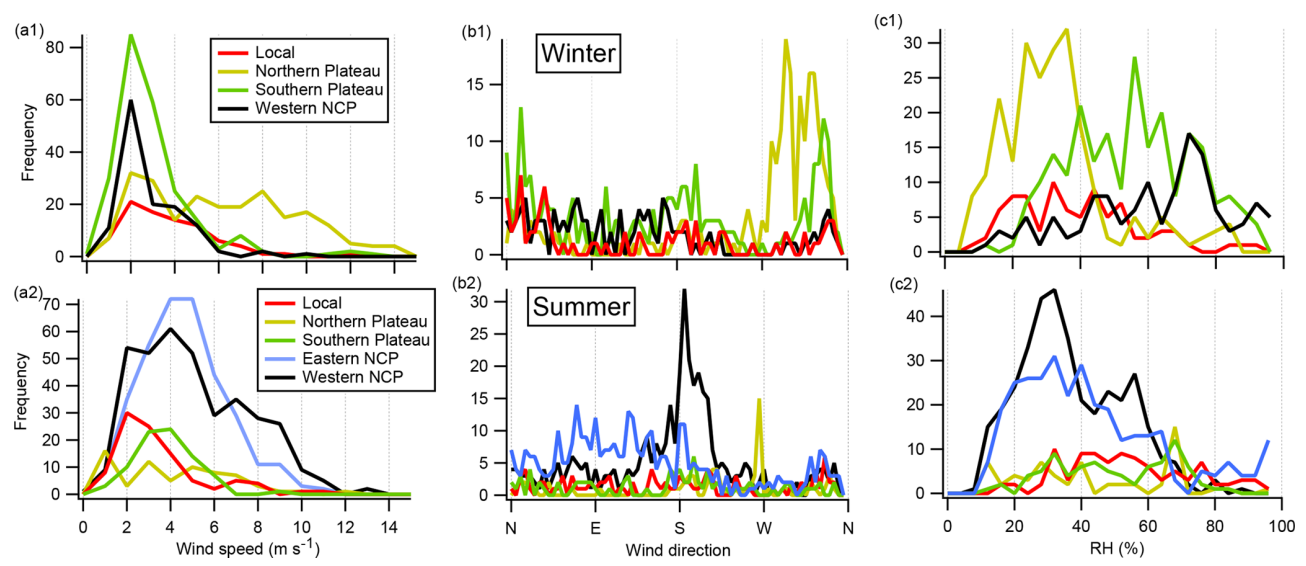

Figure 4. Frequency distributions of wind speed and direction $(z=120 \mathrm{~m})$ and $\mathrm{RH}(z=8 \mathrm{~m})$ for classified air mass types in both seasons.

consistent with the emission inventory that shows that the north-west of Beijing is dominated by lower surface emissions over Mongolia. The dilution of Beijing pollution by high wind speeds during NW air flow has been widely observed (Sun et al., 2015; Zhang et al., 2013, 2015). The BC particles during these periods had systematically lower core sizes (Fig. 5b1) and lower coatings (Fig. 5c1) and therefore smaller total particle sizes. This may result from more efficient removal processes for the more coated and larger BC particles in winter.

No significant differences $(p<0.01)$ in the physical properties of BC particles were observed between the different air mass types in summer; e.g. there is a consistent peak of $D_{\mathrm{p}} / D_{\mathrm{c}} \sim 1.4$ for all air mass types, which may suggest an almost homogenous mixture or consistent $\mathrm{BC}$ sources across a large region around Beijing in China. In winter, the range of $D_{\mathrm{p}} / D_{\mathrm{c}}$ values extended from similar values to those in the summer up to 2.5. The MMD of BC cores was most often observed to be $\sim 180 \mathrm{~nm}$ for both seasons, but it is noted that the air mass from the Southern Plateau (as the green lines show) had systematically larger MMD, and BC particles in air masses from this region also had the highest coatings and largest coated $\mathrm{BC}$ size compared to other air masses. The large BC core size and coatings observed during westerly air masses may arise from ageing of sources in central and western China during transport, though it should be noted that the trajectories presented are only for the previous $24 \mathrm{~h}$. However, the BC core size was significantly higher $(p<0.01)$ in winter than in summer during periods when Beijing received air from the Southern Plateau. This may result from a large contribution of residential heating activities in the Southern Plateau in winter which were not present in summer.

As Fig. 6 shows, the diurnal variation of $\mathrm{rBC}$ mass loading in winter showed a strong anti-correlation $\left(R^{2}=0.73\right)$ with the mixing layer height (MLH). In winter, surface cooling during the night leads to a shallow nocturnal boundary when coupled with increased emissions from heating activities, which greatly enhances surface pollution. During the day, a deeper boundary layer is re-established, resulting in a much larger volume for emissions to mix into. The diurnal variation in $\mathrm{rBC}$ is a combination of both diurnal variations in emissions and marked changes in the boundary layer structure. In summer, the night-time peak of $\mathrm{rBC}$ mass loading was absent but peaked during the morning rush hour, which may reflect the important contribution from traffic. Figure 6 shows an evident increase in BC coatings around 10:00 (all times are in local time) in winter and a slight increase around 09:00 in summer, and the coatings in winter were notably higher at night than in the day. In general, larger variations in the physical properties of $\mathrm{BC}$ were observed in winter compared to summer.

\subsection{The size distribution and mixing state of $\mathrm{BC}$}

Figure 7a gives examples of $\mathrm{BC}$ core size distributions for typical periods in both seasons. The $\mathrm{BC}$ core size distribution could be modelled as a single log-normal distribution fitted for $D_{\mathrm{c}}=100-400 \mathrm{~nm}$,

$\frac{d \mathrm{M}}{d \log D_{\mathrm{c}}}=A e^{\left(-\frac{\log ^{2}\left(D_{\mathrm{c}} / D_{0}\right)}{2 \log ^{2} \sigma_{\mathrm{g}}}\right)}$,

where $A$ is the peak concentration, $D_{\mathrm{c}}$ is the $\mathrm{BC}$ core size measured by the SP2, $D_{0}$ is the core MMD and $\sigma_{\mathrm{g}}$ is the geometric standard deviation (GSD) for the log-normal distribution. The red lines in Fig. 7a show the log-normal fitting to the observations. It is noted that some fraction of the distribution at the larger end is not fitted within the single log-normal distribution, which may require an additional moment of $\log$ normal distribution to be accounted for, as has been shown during previous urban studies (Huang et al., 2011). However, fitting a second log-normal mode will be subject to large uncertainty due to the saturation of the SP2 detector which has an upper cut-off at $D_{\mathrm{c}}=550 \mathrm{~nm}$, leading to insufficient data points to constrain such a fit. The additional $\mathrm{rBC}$ mass distribution above $550 \mathrm{~nm}$ may exist but would require instrument reconfiguration to be fully detected. The two-moment 

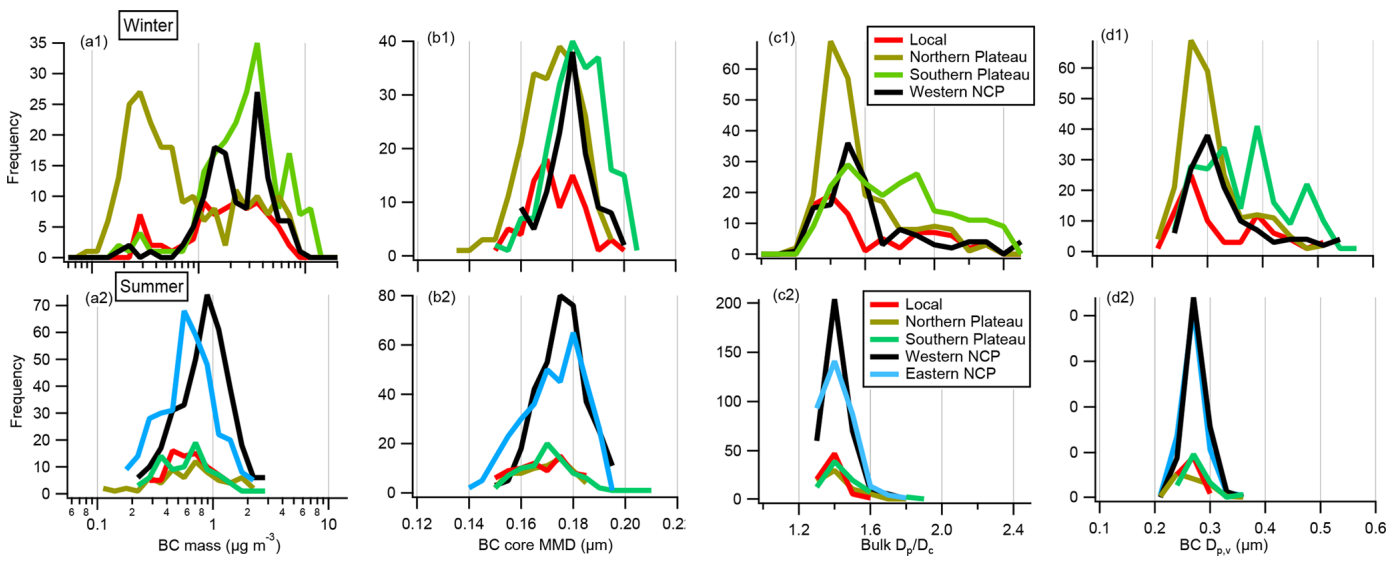

Figure 5. Histograms of $\mathrm{BC}$ mass loading, core size $\mathrm{MMD}, D_{\mathrm{p}} / D_{\mathrm{c}}$ and $D_{\mathrm{p}, \mathrm{v}}$ for different air masses in both seasons.

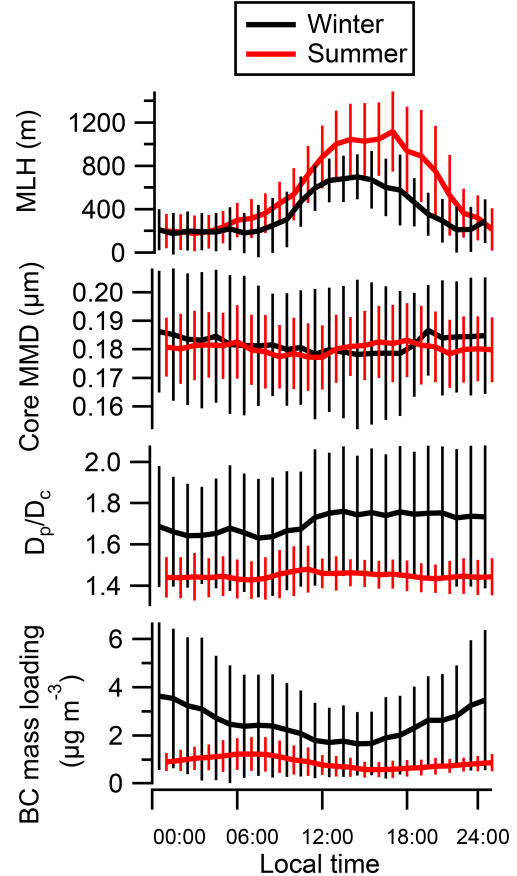

Figure 6. Diurnal variations of mixing layer height (MLH) and BCrelated properties in winter and summer. The lines show the mean at each hour and error bars denote $\pm 1 \sigma$. The $x$ value for summer is shifted by $0.5 \mathrm{~h}$ to avoid the overlap.

log-normal fitting is thus not performed in this study. The extrapolated $\mathrm{rBC}$ mass accounted for $5 \%-8 \%$ of the total $\mathrm{rBC}$ mass loading which is included for the $\mathrm{rBC}$ mass loading reported in this study.

Figure $7 \mathrm{~b}$ shows the fitting parameters of $\mathrm{BC}$ core size distribution at different levels of $\mathrm{rBC}$ mass concentration. The core size generally increased at higher $\mathrm{rBC}$ mass concentration but demonstrated considerable variability ranging between 150 and $220 \mathrm{~nm}$. BC particles were observed to have systematically larger core sizes in winter than in summer
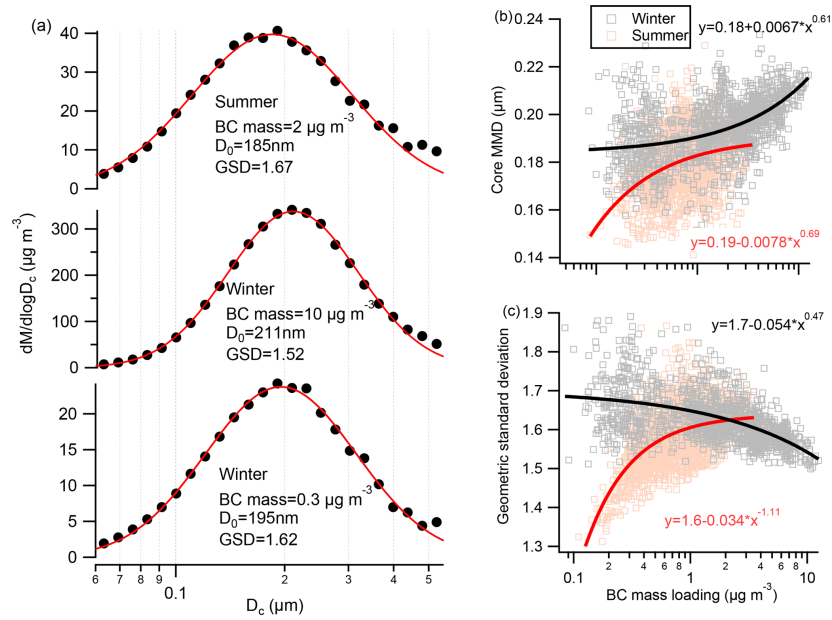

Figure 7. (a) BC core size distribution averaged over different $\mathrm{rBC}$ mass loading conditions in both seasons, showing the log-normal fitting and the fitted peak diameter $\left(D_{0}\right)$ and geometric standard deviation (GSD); (b) BC core MMD as a function of BC mass loading and parameterization; (c) BC core GSD (from the fitting) as a function of $\mathrm{BC}$ mass loading and their fitting functions. The line and error bars show the mean $\pm \sigma$ at each $\mathrm{rBC}$ mass bin.

at the same $\mathrm{rBC}$ mass concentration. In winter, the significant increase in core MMD when the $\mathrm{rBC}$ mass concentration $>5 \mu \mathrm{g} \mathrm{m}^{-3}$ may indicate that coagulation is taking place at high concentration. The increased BC coating thickness observed under these conditions is also consistent with $\mathrm{BC}$ coagulating with non-BC particles (Fig. 8). The width of the core size distribution $\sigma_{\mathrm{g}}$ in winter showed a decreasing trend at higher $\mathrm{rBC}$ mass concentration; again this is consistent with the view that coagulation may occur at high $\mathrm{rBC}$ mass concentration, reducing the width of the size distribution (Pratsinis, 1988). However, these effects may also reflect a shift in the range of sources present during periods of higher pollution levels that produces proportionally more $\mathrm{rBC}$ particles with large core sizes. In summer $\sigma_{\mathrm{g}}$ showed 


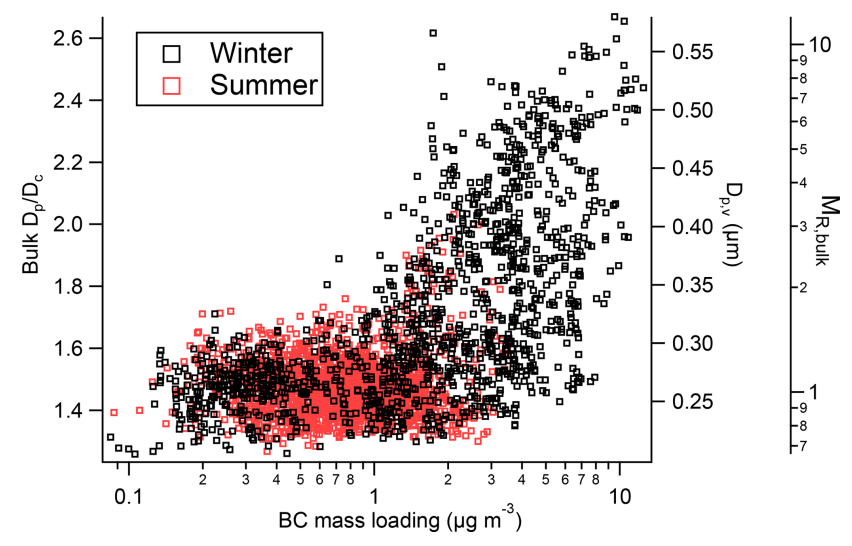

Figure 8. Mixing status of $\mathrm{BC}$ at different levels of $\mathrm{BC}$ mass loading in both seasons, with different $y$ axes showing bulk $D_{\mathrm{p}} / D_{\mathrm{c}}$, volume-weighted coated particle size $\left(D_{\mathrm{p}, \mathrm{v}}\right)$ and bulk mass mixing ratio of coating $/ \mathrm{rBC}$.

an increasing trend with $\mathrm{rBC}$ mass concentration, which may result from more diverse source contributions at higher $\mathrm{rBC}$ mass concentration. The higher $\sigma_{\mathrm{g}}$ in winter than in summer at the same $\mathrm{rBC}$ mass concentration suggests a greater complexity of sources in winter.

The core sizes observed in Beijing are significantly larger $(p<0.01)$ than those observed in London, even when the BC source profile was dominated by wood burning $(170 \mathrm{~nm})$, which may result from other sources of BC. Figure 8 shows the coating content of $\mathrm{BC}$ was similar between seasons with $M_{\mathrm{R} \text {,bulk }} 1-2$ when the $\mathrm{rBC}$ mass concentration $<2 \mu \mathrm{g} \mathrm{m}^{-3}$. During summer the coating thickness only periodically increased $\left(M_{\mathrm{R}, \text { bulk }}>2\right)$, but in winter the coating increased particularly when the $\mathrm{rBC}$ mass concentration $>3 \mu \mathrm{g} \mathrm{m}^{-3}$, showing a highly variable $M_{\mathrm{R} \text {, bulk }}$ ranging between 1.5 and 10 (bulk $D_{\mathrm{p}} / D_{\mathrm{c}} \sim 1.4-2.6$ ). Accordingly, the coated BC size $D_{\mathrm{p}, \mathrm{v}}$ peaked at $220-310 \mathrm{~nm}$ when $\mathrm{rBC}$ mass concentration $<2 \mu \mathrm{g} \mathrm{m}^{-3}$ in both seasons; however, it reached values as high as $550 \mathrm{~nm}$ under highly polluted conditions. The large variation of $\mathrm{BC}$ mixing state during wintertime when the $\mathrm{rBC}$ mass concentration $>3 \mu \mathrm{g} \mathrm{m}^{-3}$ may reflect the additional primary sources, such as the large contribution from residential sources during the cold season. However, secondary processing of the complex source mixtures under highly polluted conditions may also play an important role in increasing the coatings. Possible reasons for these differences are investigated in more detail in Sect. 4.4 and 4.6, where the $\mathrm{rBC}$ is segregated into characteristic types and compared with PMF results from the SP-AMS and $\mathrm{PM}_{1}$ respectively.

\subsection{BC segregation by size-resolved mixing state}

Figure 9 shows the $\mathrm{BC}$ core size-resolved mixing state during typical periods in both seasons, and the results obtained in London are also shown as a reference (Liu et al., 2014).
It is noted that $E_{\text {sca }}$ appears to be $<1$ at larger $D_{\mathrm{c}}$. This arises for two reasons. Firstly, the assumption of sphericity used in the Mie calculations to derive $E_{\text {sca }}$ introduces significant bias for larger BC cores with little or no coating. The resulting scattering for uncoated $\mathrm{BC}$ will be lower than that derived by Mie scattering due to geometrical influences as has been shown when comparing with T-matrix calculations (He et al., 2015; Wu et al., 2018), and this increases with rBC core size. Secondly, the $\mathrm{BC}$ at larger $D_{\mathrm{c}}$ largely results from coal combustion (Sect. 4.4), and this may have a refractive index (RI) that is different from $\mathrm{rBC}$ from traffic sources (2.26, 1,26). Both factors will lead to a lower estimated scattering cross section for uncoated $\mathrm{rBC}$, and hence $E_{\text {sca }}<1$. Since no measurements of $\mathrm{BC}$ morphology or source-dependent RI of $\mathrm{rBC}$ are available in this study, we are only able to state that this BC with larger $D_{\mathrm{c}}$ is likely to be very thinly coated and assume the particles with $E_{\mathrm{sca}}<1$ had a $D_{\mathrm{p}} / D_{\mathrm{c}}=1$. This assumption is not likely to lead to major biases since the BC at large $D_{\mathrm{c}}$ values has a lower MAC (Fig. S5), and adding material to these particles will only lead to the presence of a thin coating that will not significantly influence the resulting overall MAC (less than $8 \%$ ).

The $\mathrm{BC}$ particles were segregated according to the discontinuous distribution in $E_{\mathrm{sca}}-D_{\mathrm{c}}$ during different periods. The criteria used is shown by the dashed thick lines in Fig. 9a. Four modes of BC could be segregated: small $\mathrm{BC}\left(\mathrm{BC}_{\mathrm{sm}}\right)$ with $\mathrm{BC}$ cores smaller than $180 \mathrm{~nm}$ and coating thicknesses $<50 \mathrm{~nm}$ (assuming a core-shell structure); moderately coated $\mathrm{BC}\left(\mathrm{BC}_{\mathrm{mod}}\right)$ - moderate coating with coating thicknesses of $50-200 \mathrm{~nm}$; thickly coated $\mathrm{BC}\left(\mathrm{BC}_{\text {thick }}\right)$ with coating thicknesses $>200 \mathrm{~nm}$; and large uncoated $\mathrm{BC}$ $\left(\mathrm{BC}_{\mathrm{lg} \text {, uncoat }}\right)$ with $\mathrm{BC}$ core sizes $>180 \mathrm{~nm}$ and thicknesses $<50 \mathrm{~nm}$. The contribution of these four modes of $\mathrm{BC}$ particles to the total $\mathrm{rBC}$ number varied during different periods. In summer, the $\mathrm{BC}_{\text {thick }}$ only contributed a minor fraction of the total number throughout the experiment. The small, moderately coated and $\mathrm{BC}_{\mathrm{lg} \text {,uncoat }}$ fractions are all present in both seasons. Compared with the results in London (Fig. 9e and $\mathrm{f}$ ), the $\mathrm{BC}_{\mathrm{sm}}$ fraction was consistent with traffic influences with small core and thin coatings, and the $\mathrm{BC}_{\text {mod }}$ was broadly consistent with the wood burning observed in urban London. It is noted that the $\mathrm{BC}_{\mathrm{lg} \text {,uncoat }}$ was not important in urban London under the different air masses or source influences observed, with the mass fraction of $\mathrm{BC}_{\mathrm{gg} \text {, uncoat }}<8 \%$ and number fraction $<3 \%$ throughout the experimental period. This means $\mathrm{BC}_{\mathrm{lg} \text {, uncoat }}$ may represent a source which was uniquely present in urban Beijing but not in the UK or surrounding area.

A further analysis on the segregated $\mathrm{BC}$ core and coated size distribution (Fig. S2) shows the total size distribution of $\mathrm{BC}$ core and coated size distribution could be generally separated as two or three size distributions with $\mathrm{BC}_{\mathrm{sm}}+$ $\mathrm{BC}_{\mathrm{lg} \text {,uncoat }}, \mathrm{BC}_{\text {mod }}$ and $\mathrm{BC}_{\text {thick }}$, representing the thinly, moderately and thickly coated $\mathrm{BC}$ respectively. In particular, the thickly coated BC could well explain the additional mode 

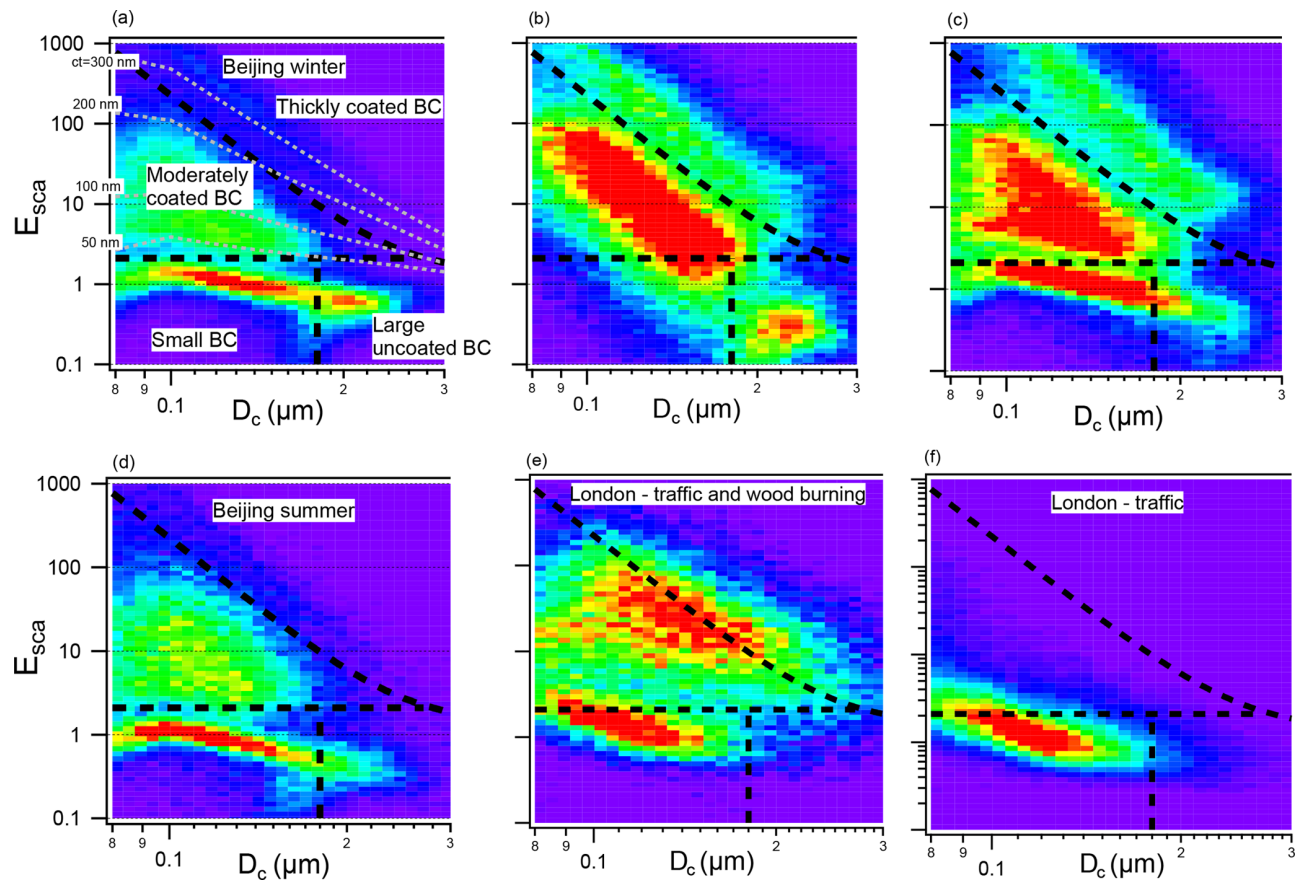

Figure 9. Scattering enhancement $\left(E_{\mathrm{sca}}\right)$ as a function of BC core size $\left(D_{\mathrm{c}}\right)$ for the three periods (as period I-III indicated in Fig. 3) in Beijing winter (a-c), Beijing summer (d), London with mixed sources (e), and London with traffic source (f). Each plot is coloured by particle number density (the colour scale is set to be red when the number density is above $70 \%$ of the maxima in each panel). The particles are separated as four groups using the borders (from top to bottom) at $y=3.38+0.000436 * \times \hat{-} 5.7, y=2.1, x=0.18$, as shown by dashed lines on each plot. The dashed grey lines on (a) denote coating thicknesses mapped on the $E_{\text {sca }}-D_{\text {c }}$ plot.

observed in the coated $\mathrm{BC}$ size distribution. This in turn suggests the apportioned $\mathrm{BC}$ modes may represent discernible primary sources or sources subject to secondary processing.

\subsection{Comparison of $\mathrm{BC}$ source estimation}

Figure 10 shows the temporal evolution of $\mathrm{rBC}$ mass in winter determined by the SP2 and SP-AMS categorized according to the different source contributions derived in Sect. 4.3 and as explored in Wang et al. (2019) respectively. PMF analysis on SP-AMS detected mass spectra identified four factors for BC-containing particles (Wang et al., 2019): fossil fuel BC (FOA_BC) containing BC from vehicle sources and coal burning, $\mathrm{BC}$ coated with biomass burning organics (BBOA_BC), BC associated with less-volatile organic coatings (OOA1_BC) and $\mathrm{BC}$ associated with semi-volatile organic coatings (OOA2_BC). Note that each PMF factor includes the refractory $\mathrm{BC}\left(C_{x}\right)$ and the non-refractory coatings associated with it. In order to directly compare with the rBC mass measured by the SP2, only the mass of the $C_{x}$ fragments in the PMF factors are used. Table 1 shows the linear correlation coefficient between the different PMF factors and the SP2-segregated BC types, with green shading highlighting the high correlation $\left(r^{2}>0.6\right)$.

The FOA_BC was not able to be further apportioned via the PMF analysis, and so this factor contains both mobile sources such as from diesel or gasoline engines and impor- tantly the coal burning emissions. Coal burning could result from both the residential and industrial sectors (Finkelman and Tian, 2018), with the former sector overwhelmingly dominating in winter but the contribution from the latter maintained throughout the year (Fig. S1). The small BC particle component is shown to be solely correlated with FOA_BC $\left(r^{2}=0.68\right)$, but FOA_BC is also correlated with

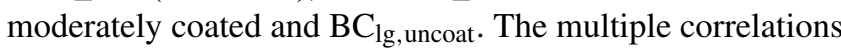
of FOA_BC with BC at different core sizes and coating thicknesses mean the fossil-fuel-related $\mathrm{BC}$ could exhibit a range of mixing states; however the $\mathrm{BC}_{\mathrm{sm}}$ particle fraction that has smaller core sizes and thinner coatings tends to be only associated with and contributes to the fossil fuel $\mathrm{BC}$ fraction.

BBOA_BC, which mostly resulted from open cooking sources in Beijing (He et al., 2010), is correlated with $\mathrm{BC}_{\bmod }$ and the $\mathrm{BC}_{\mathrm{lg} \text {, uncoat }}$ from the $\mathrm{SP} 2\left(r^{2}>0.6\right)$. Both $\mathrm{BC}$ types had high correlation with FOA and BBOA $\left(r^{2}>0.6\right)$ since the fossil fuel (excluding the part correlated with $\mathrm{BC}_{\mathrm{sm}}$ ) and biomass burning $\mathrm{BC}$ particles have similar core sizes and coating contents. The potential contributions from coal burning sources are further investigated by correlating the SPAMS-measured PAH with the SP2-segregated BC types, as the PAH is considered to be an ideal marker for coal burning (Xu et al., 2006; Sun et al., 2016a). The moderately coated and $\mathrm{BC}_{\mathrm{lg}}$,uncoat fractions are found to have the highest correlation with PAH $\left(r^{2}>0.8\right)$. This means the BC from coal 


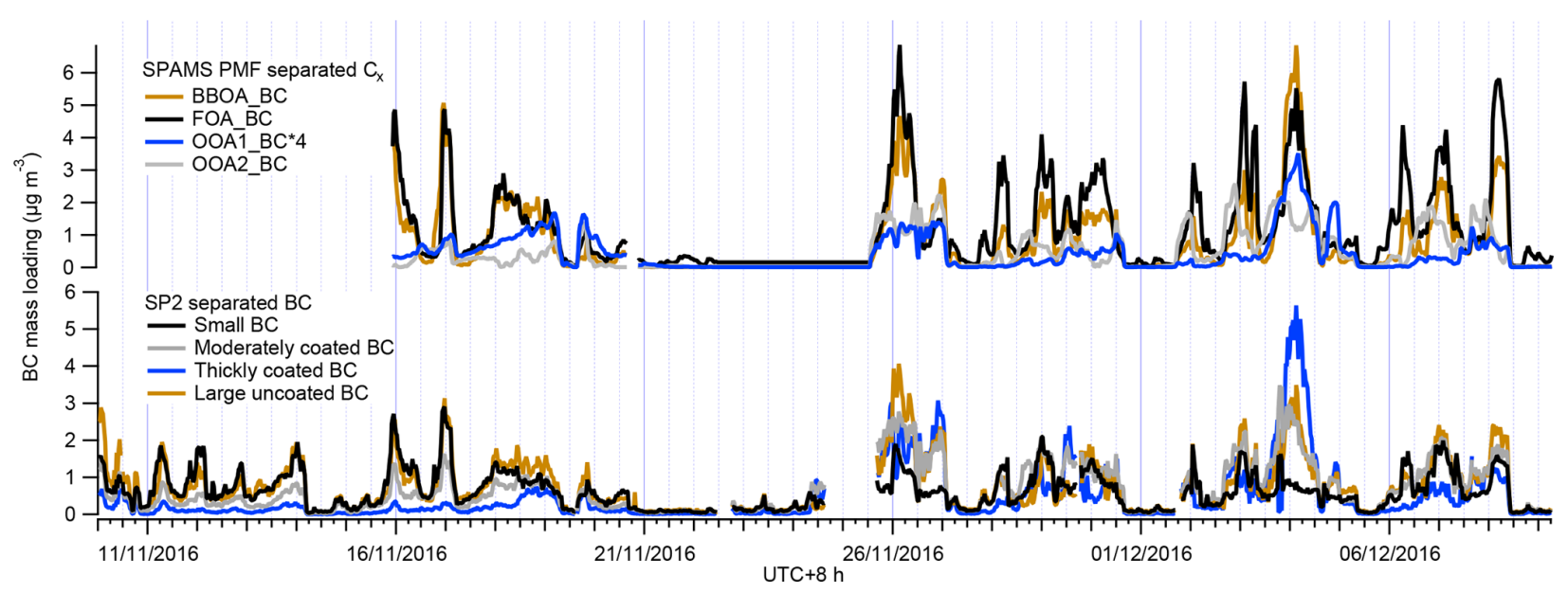

Figure 10. Time series of SP2-separated rBC mass and SP-AMS separated $C_{x}$ mass by PMF analysis.

Table 1. Pearson's correlation coefficients between the time series of SP2 and SP-AMS segregated rBC mass and PAH. The correlations with Pearson's $\mathrm{r}^{2}>0.6$ are in bold font. All correlations are significant at the 0.01 level (two-tailed).

\begin{tabular}{lrrrrr}
\hline$r^{2}(N=1406)$ & $\begin{array}{r}\text { FOA_BC } \\
\text { (fossil fuel) }\end{array}$ & $\begin{array}{r}\text { BBOA_BC } \\
\text { (biomass burning) }\end{array}$ & $\begin{array}{r}\text { OOA1_BC } \\
\text { (less volatile) }\end{array}$ & $\begin{array}{r}\text { OOA2_BC } \\
\text { (semi-volatile) }\end{array}$ & PAH_BC \\
\hline Small BC & $\mathbf{0 . 6 8}$ & 0.55 & 0.10 & 0.12 & 0.47 \\
Moderately coated BC & $\mathbf{0 . 6 1}$ & $\mathbf{0 . 6 6}$ & 0.40 & $\mathbf{0 . 6 3}$ & $\mathbf{0 . 8 1}$ \\
Thickly coated BC & 0.31 & 0.54 & $\mathbf{0 . 6 1}$ & 0.47 & 0.59 \\
Large uncoated BC & $\mathbf{0 . 7 9}$ & $\mathbf{0 . 8 5}$ & 0.42 & 0.34 & $\mathbf{0 . 8 2}$ \\
BC mass total & 0.74 & 0.85 & 0.51 & 0.51 & 0.89 \\
\hline
\end{tabular}

burning tended to contribute to both the moderately coated and the $\mathrm{BC}_{\mathrm{lg} \text {,uncoat }}$ fractions (Y. Zhang et al., 2018a) but not the $\mathrm{BC}_{\mathrm{sm}}$, which in turn indicates that the $\mathrm{BC}_{\mathrm{sm}}$ is mainly a result of mobile sources (such as traffic) rather than coal burning. Previous studies found that the coal emission in urban China may have a larger BC core size compared to traffic sources (Wang et al., 2016; Y. Zhang et al., 2018a) and larger BC cores in the cold season (Yang et al., 2018). This

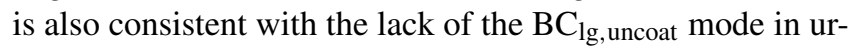
ban London where there was no coal burning present in the city (Fig. 9). Given that biomass burning was also correlated with moderately coated and $\mathrm{BC}_{\mathrm{lg} \text {,uncoat }}$ fractions $\left(r^{2}>0.6\right)$, analyses limited to the size-resolved mixing state alone may not be able to distinguish the $\mathrm{BC}$ particles derived from coal and biomass burning in urban Beijing. This may be because the contribution of biomass burning to $\mathrm{BC}$ was significantly lower $(p<0.01)$ than that from fossil fuel in Beijing (Zhang et al., 2017), and the open biomass burning was only sporadically significant during spring and autumn harvest time over the NCP region (Chen et al., 2017). In addition, even some of the coal burning contribution, especially for the coal from residential use, may be attributed as biomass burning if using levoglucosan as a marker (Yan et al., 2018), which may lead to some fraction of BBOA identified by the SP-AMS containing some fraction of coal burning. $\mathrm{BC}_{\bmod }$ is consis- tent with wood burning in urban London, but $\mathrm{BC}_{\mathrm{lg}}$,uncoat is not present from these sources (Fig. 9e and f). It is therefore

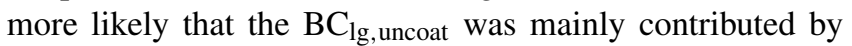
coal combustion.

The $\mathrm{BC}_{\text {thick }}$ or $\mathrm{BC}_{\text {mod }}$ fraction is well correlated $\left(r^{2}>0.6\right)$ with the BC coated with less-volatile organics (OOA1_BC) or semi-volatile organics (OOA2_BC) respectively. This means the coating composition would mostly contain lessvolatile organic species when BC was thickly coated, whereas the moderate coating $\mathrm{BC}$ particle fraction mainly contained semi-volatile species. The coal burning or biomass burning contributions are also significant in the $\mathrm{BC}_{\mathrm{mod}}$ fraction, which means these primary sources may also emit considerable semi-volatile species internally mixed with BC. Note that the absolute values of $\mathrm{rBC}$ mass from SP-AMS or SP2 had not necessarily corresponded with each other for the correlated factors; e.g. the OOA2_BC is higher than OOA1_BC but vice versa for the SP2 factors. This may result from different responses and sensitivities for the measurement techniques of both instruments at different levels of $\mathrm{BC}$ mixing state. 


\subsection{Diurnal variation of different types of BC}

Figure 11 shows the diurnal variation of the four different rBC types classified by the SP2. In winter all BC types anticorrelated with the diurnal evolution of MLH, whereas in summer all $\mathrm{BC}$ types exhibited a morning rush-hour peak. For $\mathrm{BC}_{\text {thick }}$ in winter, the average was significantly higher $(p<0.01)$ than the median, indicating the sporadic occurrence of the thickly coated $\mathrm{BC}$. There was no discernible difference in the diurnal patterns of the absolute mass loadings of the different $\mathrm{BC}$ types, which means similar emission sources, and the PBL development may have controlled the diurnal pattern of different BC types to a similar extent. Nevertheless, differences could be identified by relative abundances of different $\mathrm{BC}$ types as discussed in the following section.

The diurnal variation of the number or mass fraction of $\mathrm{BC}_{\mathrm{sm}}$ (Fig. 11c) peaked at 08:00 and 07:00 in the winter and summer respectively, which corresponded with the morning rush hour. This is consistent with the identified possible traffic contribution to the $\mathrm{BC}_{\mathrm{sm}}$ fraction by comparison with the SP-AMS factors (Sect. 4.4). The diurnal variation of this $\mathrm{BC}$ mode also had high correlation with $\mathrm{NO}_{x}$ in both seasons $\left(r^{2}>0.7\right)$, with the morning rush hour occurring slightly later in winter than in summer, which further confirms the likely origin of the traffic source. The correlation between the $\mathrm{NO}_{x}$ concentration and different $\mathrm{BC}$ types is further evaluated by a multilinear regression function, expressed as Eq. (7). The fitting parameters are summarized in Table 2.

$$
\begin{aligned}
{\left[\mathrm{NO}_{x}\right] } & =\mathrm{a} 0+\mathrm{a} 1 *\left[\mathrm{BC}_{\mathrm{sm}}\right]+\mathrm{a} 2 *\left[\mathrm{BC}_{\mathrm{mod}}\right] \\
& +\mathrm{a} 3 *\left[\mathrm{BC}_{\text {thick }}\right]+\mathrm{a} 4 *\left[\mathrm{BC}_{\mathrm{lg}, \text { uncoat }}\right]
\end{aligned}
$$

Among all BC types, a1 shows the highest value in both seasons, which indicates the strong correlation $\left(r^{2}>\right.$ 0.7 ) between the $\mathrm{BC}_{\mathrm{sm}}$ mass fraction and the $\mathrm{NO}_{x}$ concentration, with almost identical emission factor of 68$72 \mathrm{ppbv} \mathrm{NO}_{x}\left(\mu \mathrm{g} \mathrm{m}^{-3}\right)^{-1}$ of $\mathrm{BC}_{\mathrm{sm}}$. In winter, the $\mathrm{BC}_{\bmod }$ also contributed some fraction of $\mathrm{NO}_{x}$, whereas in summer the contribution of this $\mathrm{BC}$ type to $\mathrm{NO}_{x}$ was almost negligi-

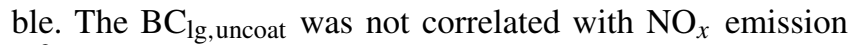
$\left(r^{2}<0.3\right)$, which in turn suggests the coal combustion may not emit significant $\mathrm{NO}_{x}$ (Zhao et al., 2013; Wang and Hao, 2012). The $\mathrm{BC}_{\mathrm{sm}}$ fraction contributed the most in summer (50\%-60\% in number and $40 \%$ in mass) and the second most in winter $(30 \%-40 \%$ in number and $30 \%$ in mass). These BC particles had smaller core size and thin coatings, and thus they contributed more significantly to the number than the mass. A similar number fraction of the $\mathrm{BC}$ was also present in urban London (Liu et al., 2014) and Paris (Laborde et al., 2013) and had also been identified to be dominated by traffic sources.

$\mathrm{BC}_{\mathrm{mod}}$ showed comparable contribution in both seasons ( $40 \%-50 \%$ in mass or $20 \%-25 \%$ in number). The fraction of these particles slightly increased throughout the afternoon for both seasons, and this may partly result from daytime photochemical processing, though this BC type was also significantly associated with primary sources (Sect. 4.4). The $\mathrm{BC}_{\text {thick }}$ fraction showed no apparent diurnal pattern (note that $\mathrm{BC}_{\text {thick }}$ mass fraction in summer was minor $\sim 5 \%$ ) and only made a significant contribution at higher pollution levels (Sect. 4.6).

$\mathrm{BC}_{\mathrm{lg}, \text { uncoat }}$ contributed a significant mass fraction (30\%$40 \%$ in winter and $40 \%$ in summer) but contributed little to the number $(<10 \%)$ because of the large core sizes. The mass fraction of these $\mathrm{BC}$ particles had a pronounced nighttime peak in winter, consistent with the view that this BC type may be contributed by coal burning (also identified by comparing with the PAH factor in Sect. 4.4), because in the cold season there were significant residential heating activities at night which may use coal as fuel (Chen et al., 2006). This night-time peak in the mass fraction of $\mathrm{BC}_{\mathrm{lg} \text {, uncoat was }}$ missing in summer due to lack of these heating activities. Nevertheless, the $\mathrm{BC}_{\mathrm{lg} \text {, uncoat }}$ mass fraction remained substantial in summer, comparable with that of the $\mathrm{BC}_{\mathrm{sm}}$ fraction at around $40 \%$. This may be because of the coal consumption from the industrial sector that is maintained throughout the year (Fig. S1).

To account for the dilution effect resulting from the development of the PBL, the $\mathrm{rBC}$ mass loading was multiplied by the MLH for every half hour throughout the day. The MLH-corrected $\mathrm{rBC}$ mass for each BC type is shown in Fig. $11 \mathrm{~b}$ and provides a way of assessing the influence of $\mathrm{BC}$ emissions, although there are uncertainties associated with the MLH determination from ceilometer measurements (Kotthaus and Grimmond, 2018). All BC types showed a peak in the MLH-corrected concentration at night in winter but showed a night-time minimum in summer, which may reflect a generally higher emission during night-time in winter but not in the summer. During the daytime between the hours of 06:00 and 19:00, $\mathrm{BC}_{\mathrm{sm}}$ mass corrected for the MLH was similar in both seasons, suggesting that $\mathrm{BC}_{\mathrm{sm}}$ may have comparable emission rates between seasons, consistent with the view that these $\mathrm{BC}$ particles may be dominated by the

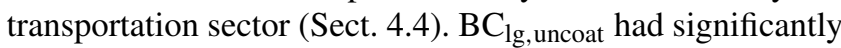
higher $(p<0.01)$ emission at night in winter than in summer by a factor of 2.5 , which is also consistent with the higher coal consumption from the residential sector in winter.

\section{6 $\quad \mathrm{BC}$ at different pollution levels}

Given the complexity of the sources contributing to $\mathrm{BC}$ in Beijing, the relative primary source contributions and its interaction with other aerosol species may vary with the overall level of pollution, and this in turn may change both the mixing state and the optical properties of BC. Figure 12 shows mass fractions of different $\mathrm{BC}$ types at different $\mathrm{PM}_{1}$ level determined by the total mass of AMS + SP2. The traffic-like $\mathrm{BC}_{\mathrm{sm}}$ (Fig. 12a) was a constant fraction of the total mass at lower pollution levels (when $\mathrm{PM}_{1}<50 \mu \mathrm{g} \mathrm{m}^{-3}$ ) that was 

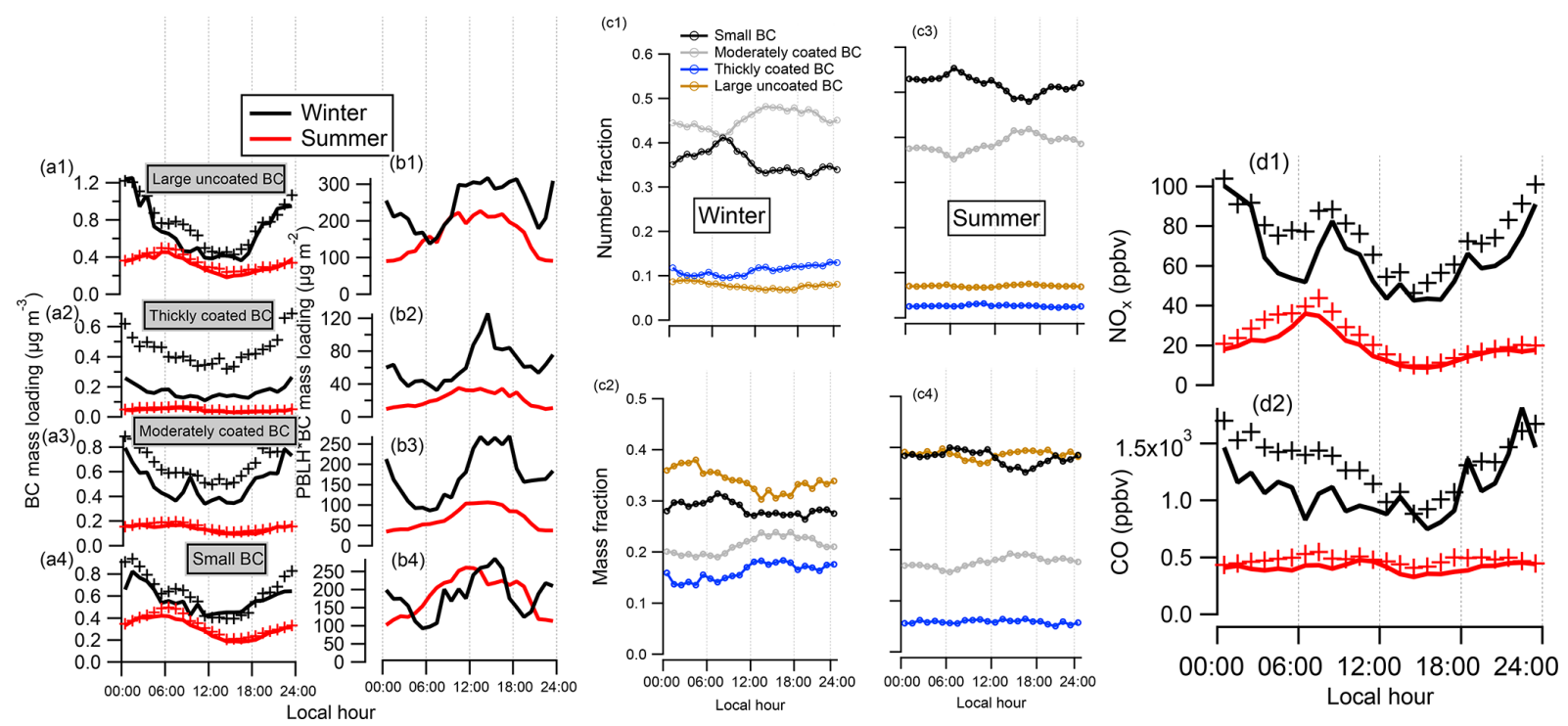

Figure 11. Diurnal variation of the rBC mass segregated by their SP2 characteristics in both seasons. (a) shows the median (solid line) and mean (markers) at each hour; (b) shows the median value of PBLH-corrected rBC mass; (c) shows the number and mass fractions for each $\mathrm{BC}$ type; (d) shows the $\mathrm{NO}_{x}$ and $\mathrm{CO}$.

Table 2. Multilinear regression for Eq. (7) among $\mathrm{NO}_{x}$ and different $\mathrm{BC}$ types.

\begin{tabular}{lrrrrr}
\hline $\begin{array}{l}\mathrm{NO}_{x} \text { with } \\
\mathrm{BC} \text { types }\end{array}$ & $\mathrm{a} 1$ & $\mathrm{a} 2$ & $\mathrm{a} 3$ & $\mathrm{a} 4$ & $\mathrm{a} 0$ \\
\hline Winter & $72.3 \pm 3.2$ & $21.3 \pm 3.0$ & $16.3 \pm 2.1$ & 0 & $8.8 \pm 1.3$ \\
Summer & $68.4 \pm 4.7$ & 0 & 0 & 0 & $1.15 \pm 0.77$ \\
\hline
\end{tabular}

around $30 \%$ and $40 \%$ in winter and summer respectively. The decreased mass fraction of $\mathrm{BC}_{\mathrm{sm}}$ at higher pollution levels occurs in both seasons but is particularly marked in winter and matched by an equal and opposite increase in the mass fraction of $\mathrm{BC}_{\text {thick }}$ under high pollution loadings. The $\mathrm{BC}_{\mathrm{lg} \text {,uncoat }}$ fraction (Fig. 12b) was similar in magnitude to the $\mathrm{BC}_{\mathrm{sm}}$ fraction in summer across all levels of pollution, which means the coal-burning-like $\mathrm{BC}$ was almost as important as the traffic source. In winter, the contribution of $\mathrm{BC}_{\mathrm{lg} \text {, uncoat }}$ mass was slightly higher than the traffic-like $\mathrm{BC}_{\mathrm{sm}}$ mass fraction, whereas in summer the $\mathrm{BC}_{\mathrm{sm}}$ mass was more significant. At the higher pollution levels in winter, some of the $\mathrm{BC}_{\mathrm{lg} \text {,uncoat }}$ may be also contributed by coagulation.

The increase in the mass fraction of $\mathrm{BC}_{\text {thick }}$ at higher pollution levels (Fig. 12d) and the commensurate reduction in the mass fraction of $\mathrm{BC}_{\mathrm{sm}}$ (Fig. 12a) are very striking, especially when $\mathrm{PM}_{1}>100 \mu \mathrm{g} \mathrm{m}^{-3}$ with $\mathrm{rBC}$ mass loading $>\sim$ $2 \mu \mathrm{g} \mathrm{m}^{-3}$. Under these conditions, $\mathrm{BC}_{\text {thick }}$ may be up to $50 \%$ of the total $\mathrm{rBC}$ mass. The coatings on these $\mathrm{BC}_{\text {thick }}$ particles were largely contributed by secondary species according to the SP-AMS analysis (Sect. 4.4). In summer, there were no periods of very high pollution in excess of $100 \mu \mathrm{g} \mathrm{m}^{-3}$ and the $\mathrm{BC}_{\text {thick }}$ mass fraction was less than $10 \%$, though the trends in the fraction of $\mathrm{BC}_{\mathrm{sm}}$ and $\mathrm{BC}_{\text {thick }}$ with pollu- tion loading are the same in both seasons. This is entirely consistent with coagulation of particulate under very high concentrations. Under such conditions the very high numbers of $\mathrm{BC}_{\mathrm{sm}}$ may coagulate rapidly with the large numbers of non-BC accumulation mode pollution aerosol that is composed largely of secondary material; this process can happen rapidly at high number concentrations and lead to the small $\mathrm{BC}$ particles gaining very think coatings with no change in the core mass distribution (see also Fig. 9). High concentrations of secondary precursor during the higher-pollution episode in the gas phase may lead to nucleation and new particle formation, or size growth on preexisting particles. A further analysis shows high number concentration of particles also corresponded with higher mass concentrations, indicating that the new particle formation and primary emission coincided with particle size growth. These processes will in turn promote the high coatings on BC.

At higher $\mathrm{PM}_{1}$ level in winter, the increased mass fraction of $\mathrm{BC}_{\text {thick }}$ also led to a decrease in $\mathrm{BC}_{\text {mod }}$. However, in summer the $\mathrm{BC}_{\text {mod }}$ fraction increased when $\mathrm{PM}_{1}>50 \mu \mathrm{g} \mathrm{m}{ }^{-3}$; this high-pollution event has previously been shown to be dominated by secondary species (Sun et al., 2015). The higher fraction of $\mathrm{BC}_{\mathrm{mod}}$ in winter than in summer at the same pollution level may result from greater primary emis- 

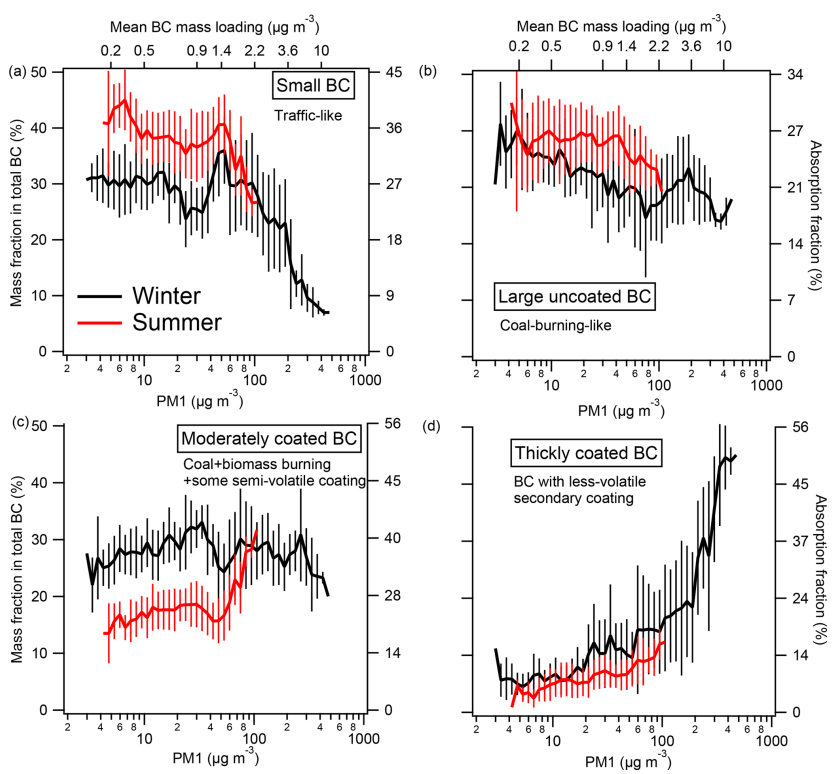

Figure 12. The mass (left $y$ axis) contributions of different BC types at different pollution levels during winter and summer. The mean contribution of the absorption corresponding to the mass fraction for each $\mathrm{BC}$ type is shown on the right $y$ axis. The mass fraction of each $\mathrm{BC}$ type is the average \pm standard deviation at each $\mathrm{PM}_{1}$ bin. The top axis shows the averaged $\mathrm{rBC}$ mass loading at each $\mathrm{PM}_{1}$ bin, and the right axis indicates the average absorption fraction corresponding with each $\mathrm{rBC}$ mass fraction.

sions (i.e. more residential coal burning in the cold season) or more condensable semi-volatile species at colder temperatures. The mass contribution of $\mathrm{BC}_{\mathrm{mod}}$ and $\mathrm{BC}_{\text {thick }}$ in summer was lower than in winter at the same pollution level, possibly as a result of higher ambient temperatures in summer reducing the amount of semi-volatile material partitioning to the particles.

The contribution of absorption coefficient is calculated based on single-particle information shown in Fig. S4 (note that the coating is assumed to be non-absorbing here). The right axis of Fig. 12 shows the mean contribution of absorption corresponding to the mass fraction for each $\mathrm{BC}$ type, implying that different $\mathrm{BC}$ types have varying absorption efficiency, but the contribution on absorption is determined by both mass loading and MAC. Figure S5 shows the histogram of occurrence for $\mathrm{MAC}_{550}$ of each $\mathrm{BC}$ type during the experimental period: the $\mathrm{BC}_{\mathrm{sm}}$ and largely uncoated $\mathrm{BC}$ had an average $\mathrm{MAC}_{550}$ of about 7.3 and $5.3 \mathrm{~m}^{2} \mathrm{~g}^{-1}$ respectively; and $\mathrm{BC}_{\mathrm{lg} \text {,uncoat }}$ had a lower MAC because of its larger core size, which is consistent with Mie calculation. The $\mathrm{BC}_{\text {mod }}$ and $\mathrm{BC}_{\text {thick }}$ had an average MAC of 11.2 and $12.4 \mathrm{~m}^{2} \mathrm{~g}^{-1}$ respectively.

Figure 13 shows both modelled and PAX-measured $\mathrm{MAC}_{870}$ at different pollution levels, the results agree to within $15 \%$. For both seasons, when $\mathrm{PM}_{1}<50 \mu \mathrm{g} \mathrm{m}^{-3}$, the measured absorption efficiency of $\mathrm{BC}$ showed little de-

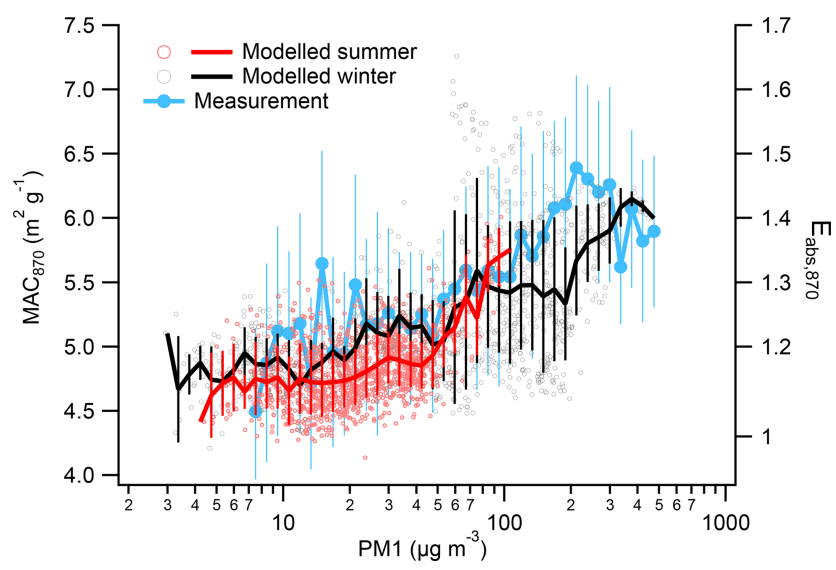

Figure 13. The modelled and measured $\mathrm{MAC}_{870}$ and $E_{\mathrm{abs}}$ at different pollution level.

pendence on the concentration of particulate matter with $\mathrm{MAC}_{870} 4.9 \pm 0.4 \mathrm{~m}^{2} \mathrm{~g}^{-1}$ and $4.7 \pm 0.3 \mathrm{~m}^{2} \mathrm{~g}^{-1}$ in winter and summer respectively. The absorption at $\lambda=870 \mathrm{~m}$ is deemed to be unaffected by brown carbon (Sun et al., 2007). The $\mathrm{MAC}_{870}$ for uncoated $\mathrm{BC}$ was calculated to be $4.3 \pm$ $0.2 \mathrm{~m}^{2} \mathrm{~g}^{-1}$ for both seasons, so the enhancement of absorption efficiency $\left(E_{\text {abs }}\right)$ is calculated as the modelled $\mathrm{MAC}_{870}$ normalized by this value. $E_{\mathrm{abs}, 870}$ significantly increased at $\mathrm{PM}_{1}>50 \mu \mathrm{g} \mathrm{m}^{-3}$ up to $1.4 \pm 0.1$ and $1.6 \pm 0.1$ for summer and winter respectively. This increase in absorbing capacity of $\mathrm{BC}$ at higher pollution levels implies that both primary emission and secondary processing may both contribute to the coatings and subsequent increased absorption. It also highlights the potential for additional feedback between pollution and radiation under very high pollution loadings (Y. Zhang et al., 2018b). There was a wide variability in MAC or $E_{\text {abs }}$ at $\mathrm{PM}_{1}$ concentrations of between 100 and $200 \mathrm{\mu g} \mathrm{m}^{-3}$. In addition, the mean PAX-measured $\mathrm{MAC}_{870}$ was higher than the modelled results by $20 \%$ at this pollution level. This suggests complex processes at this moderate pollution level where a large variability of $\mathrm{BC}$ coating content was present, but a single mixing scenario based on Mie calculation is not able to fully explain the measurements of absorption. The $\mathrm{MAC}_{870}$ slightly decreased at very high $\mathrm{PM}_{1}$, i.e. $>300 \mu \mathrm{g} \mathrm{m}^{-3}$, and this decrease is more pronounced for measurement (the grey line shows) than Miebased modelling. This may result from the shadowing effect that very thick coatings may shield incident photons from the core, particularly when the coatings are absorbing (He et al., 2015; X. Zhang et al., 2018).

\section{Conclusions}

In order to probe the sources and processes governing atmospheric black carbon in Beijing, measurements were performed in both winter and summer using an SP2, and the core 
size and coating thickness were examined using the singleparticle data. Higher rBC mass loading with more variable coatings was found in winter than in summer. The air mass from the Southern Plateau brought BC with the largest core size and coatings in winter, indicating the appreciable regional influence, whereas in summer the characteristics of $\mathrm{BC}$ were relatively independent of air mass direction. In contrast to equivalent measurements in London, where two particle types were observed, corresponding to traffic and wood burning, other types were observed in Beijing, probably reflecting a more complex mixture of sources. rBC number and mass concentrations were quantified according to the following four particle types: small thinly coated $\mathrm{BC}$, moderately coated BC, thickly coated BC and large thinly coated BC. By comparison with other measurements, in particular a factorization of coating materials from the SP-AMS, these were assigned to different soot sources.

The small thinly coated $\mathrm{rBC}$ fraction was associated with traffic emissions and made up for $30 \%$ and $40 \%$ of the rBC mass in winter and summer respectively. This particle fraction was strongly associated with $\mathrm{NO}_{x}$, though the implied ratio of $14 \mathrm{ng} \mathrm{m}^{-3} \mathrm{ppb}^{-1}$ was lower than the values of 18 $28 \mathrm{ng} \mathrm{m}^{-3} \mathrm{ppb}^{-1}$ reported for London, likely due to differences in the emissions fleet, such as a more widely used gasoline engine in Beijing (Wang et al., 2009). The large thinly coated $\mathrm{rBC}$ could be associated with coal combustion and corresponded to around $30 \%-40 \%$ and $40 \%$ of the rBC mass in winter and summer respectively.

The moderately coated particle fraction made up $40 \%-$ $50 \%$ of the rBC mass and was associated with both emissions and atmospheric processes. As a result, the original source of these particles is currently ambiguous; it is possible that this class has multiple contributions. The thickly coated particle fraction was mainly present during the winter heavy haze events when $\mathrm{PM}_{1}$ was greater than $200 \mu \mathrm{g} \mathrm{m}^{-3}$ or the $\mathrm{rBC}$ mass loading was greater than $4 \mu \mathrm{g} \mathrm{m}^{-3}$. During these events, these particles made up for around $20 \%-45 \%$ of the $\mathrm{rBC}$ mass and the coatings could be associated with secondary species, implying that these are $\mathrm{rBC}$ particles that have undergone some form of atmospheric processing. Given the thick coatings, it would be expected that these particles would exhibit higher mass absorption and scattering coefficients, higher hygroscopicities (thus high optical thickness in the upper boundary layer) and greater scavenging potential (thus shorter atmospheric lifetime). These large BC particles importantly enhanced the absorption efficiency at high pollution levels, and reduction of emissions of these large $\mathrm{BC}$ particles and the precursors of the associated secondary coating will be an effective way of mitigating the heating effect of $\mathrm{BC}$ in urban environments.
Data availability. Processed data are available through the APHH project archive at the Centre for Environmental Data Analysis (http://data.ceda.ac.uk/badc/aphh/data/beijing/, last access: December 2018, CEDA Archive, 2018). Raw data are archived at the University of Manchester and are available on request. 


\section{Appendix A}

Table A1. Symbols and abbreviations.

\begin{tabular}{ll}
\hline Symbols and abbreviations & Meaning \\
\hline $\mathrm{BC}_{\mathrm{sm}}$ & Small BC \\
$\mathrm{BC}_{\mathrm{mod}}$ & Moderately coated BC \\
$\mathrm{BC}_{\text {thick }}$ & Thickly coated BC \\
$\mathrm{BC}_{\mathrm{g}, \text { uncoat }}$ & Large and uncoated BC \\
$\mathrm{FOA}$ & Fossil fuel organic aerosol \\
$\mathrm{BBOA}$ & Biomass burning organic aerosol \\
OOA1 & Low-volatility organic aerosol \\
OOA2 & Semi-volatile organic aerosol \\
PBL & Planetary boundary layer \\
PMF & Positive matrix factorization \\
$\mathrm{rBC}$ & Refractory BC \\
$\mathrm{SP} 2$ & Single-particle soot photometer \\
$D_{\mathrm{c}}$ & BC core diameter \\
$D_{\mathrm{p}}$ & Coated BC diameter \\
$\mathrm{rBC}$ & Refractory BC \\
$\mathrm{MAC}$ & Mass absorption cross section \\
$\mathrm{MMD}$ & Mass median diameter \\
\hline
\end{tabular}


Supplement. The supplement related to this article is available online at: https://doi.org/10.5194/acp-19-6749-2019-supplement.

Author contributions. DL, JDA and MJF designed the research; JDA, DL, RJ, JW, CY, HC, MJF, CX, JL, FS, XG, YS and PF performed experiments; DL performed the data analysis; JW and XG analysed the SP-AMS data; SK and SG analysed the MLH data; JL and FS analysed the $\mathrm{NO}_{x}$ and CO data; DL, JW, JDA and HC wrote the paper.

Competing interests. The authors declare that they have no conflict of interest.

Special issue statement. This article is part of the special issue "In-depth study of air pollution sources and processes within Beijing and its surrounding region (APHH-Beijing) (ACP/AMT interjournal SI)". It is not associated with a conference.

Acknowledgements. This work was supported through the UK Natural Environment Research Council (grant refs. NE/N007123/1, NE/N00695X/1 and NE/N00700X/1) and the National Natural Science Foundation of China (41571130024, 41571130034, 21777073).

Financial support. This research has been supported by the UK Natural Environment Research Council (grant nos. NE/N007123/1, NE/N00695X/1 and NE/N00700X/1) and the National Natural Science Foundation of China (grant nos. 41571130024, 41571130034 and 21777073).

Review statement. This paper was edited by Frank Keutsch and reviewed by two anonymous referees.

\section{References}

Baumgartner, J., Zhang, Y., Schauer, J. J., Huang, W., Wang, Y., and Ezzati, M.: Highway proximity and black carbon from cookstoves as a risk factor for higher blood pressure in rural China, $\mathrm{P}$. Natl. Acad. Sci. USA, 111, 13229-13234, 2014.

Bernardoni, V., Calzolai, G., Chiari, M., Fedi, M., Lucarelli, F., Nava, S., Piazzalunga, A., Riccobono, F., Taccetti, F., and Valli, G.: Radiocarbon analysis on organic and elemental carbon in aerosol samples and source apportionment at an urban site in Northern Italy, J. Aerosol Sci., 56, 88-99, 2013.

Bohren, C. F. and Huffman, D. R.: Absorption and scattering of light by small particles, John Wiley \& Sons, 2008.

Bond, T. C. and Bergstrom, R. W.: Light absorption by carbonaceous particles: An investigative review, Aerosol Sci. Technol., 40, 27-67, 2006.

Bond, T. C., Doherty, S. J., Fahey, D., Forster, P., Berntsen, T., DeAngelo, B., Flanner, M., Ghan, S., Kärcher, B., and Koch, D.:
Bounding the role of black carbon in the climate system: A scientific assessment, J. Geophys. Res.-Atmos., 118, 5380-5552, 2013.

Cao, J. J., Wu, F., Chow, J. C., Lee, S. C., Li, Y., Chen, S. W., An, Z. S., Fung, K. K., Watson, J. G., Zhu, C. S., and Liu, S. X.: Characterization and source apportionment of atmospheric organic and elemental carbon during fall and winter of 2003 in Xi' an, China, Atmos. Chem. Phys., 5, 3127-3137, https://doi.org/10.5194/acp5-3127-2005, 2005.

CEDA Archive: APHH: Atmospheric measurements and model results for the Atmospheric Pollution \& Human Health in a Chinese Megacity, available at: http://data.ceda.ac.uk/badc/aphh/ data/beijing/, last access: December 2018.

Chen, J., Li, C., Ristovski, Z., Milic, A., Gu, Y., Islam, M. S., Wang, S., Hao, J., Zhang, H., and He, C.: A review of biomass burning: Emissions and impacts on air quality, health and climate in China, Sci. Total Environ., 579, 1000-1034, 2017.

Chen, Y., Zhi, G., Feng, Y., Fu, J., Feng, J., Sheng, G., and Simoneit, B. R.: Measurements of emission factors for primary carbonaceous particles from residential raw-coal combustion in China, Geophys. Res. Lett., 33, L20815, https://doi.org/10.1029/2006GL026966, 2006.

Draxler, R. R. and Hess, G.: An overview of the HYSPLIT_4 modelling system for trajectories, Aust. Meteorol. Mag., 47, 295308, 1998.

Fierce, L., Bond, T. C., Bauer, S. E., Mena, F., and Riemer, N.: Black carbon absorption at the global scale is affected by particle-scale diversity in composition, Nat. Commun., 7, 12361, https://doi.org/10.1038/ncomms12361, 2016.

Finkelman, R. B. and Tian, L.: The health impacts of coal use in China, Int. Geol. Rev., 60, 579-589, 2018.

Gao, R., Schwarz, J., Kelly, K., Fahey, D., Watts, L., Thompson, T., Spackman, J., Slowik, J., Cross, E., and Han, J.-H.: A novel method for estimating light-scattering properties of soot aerosols using a modified single-particle soot photometer, Aerosol Sci. Tech., 41, 125-135, 2007.

He, C., Liou, K.-N., Takano, Y., Zhang, R., Levy Zamora, M., Yang, P., Li, Q., and Leung, L. R.: Variation of the radiative properties during black carbon aging: theoretical and experimental intercomparison, Atmos. Chem. Phys., 15, 11967-11980, https://doi.org/10.5194/acp-15-11967-2015, 2015.

He, L.-Y., Lin, Y., Huang, X.-F., Guo, S., Xue, L., Su, Q., Hu, M., Luan, S.-J., and Zhang, Y.-H.: Characterization of highresolution aerosol mass spectra of primary organic aerosol emissions from Chinese cooking and biomass burning, Atmos. Chem. Phys., 10, 11535-11543, https://doi.org/10.5194/acp-10-115352010, 2010.

Healy, R. M., Sciare, J., Poulain, L., Kamili, K., Merkel, M., Müller, T., Wiedensohler, A., Eckhardt, S., Stohl, A., Sarda-Estève, R., McGillicuddy, E., O'Connor, I. P., Sodeau, J. R., and Wenger, J. C.: Sources and mixing state of size-resolved elemental carbon particles in a European megacity: Paris, Atmos. Chem. Phys., 12, 1681-1700, https://doi.org/10.5194/acp-12-1681-2012, 2012.

Hodnebrog, Ø., Myhre, G., and Samset, B. H.: How shorter black carbon lifetime alters its climate effect, Nat. Commun., 5, 5065, 2014.

Huang, X. F., Gao, R., Schwarz, J., He, L. Y., Fahey, D., Watts, L., McComiskey, A., Cooper, O., Sun, T. L., and Zeng, L. W.: Black carbon measurements in the Pearl River 
Delta region of China, J. Geophys. Res.-Atmos., 116, D12208, https://doi.org/10.1029/2010JD014933, 2011.

Jayne, J. T., Leard, D. C., Zhang, X., Davidovits, P., Smith, K. A., Kolb, C. E., and Worsnop, D. R.: Development of an Aerosol Mass Spectrometer for Size and Composition Analysis of Submicron Particles, Aerosol Sci. Technol., 33, 49-70, https://doi.org/10.1016/S0021-8502(98)00158-X, 2000.

Kopp, R. E. and Mauzerall, D. L.: Assessing the climatic benefits of black carbon mitigation, P. Natl. Acad. Sci. USA, 107, 1170311708, 2010.

Kotthaus, S. and Grimmond, C. S. B.: Atmospheric Boundary Layer Characteristics from Ceilometer Measurements Part 1: A new method to track mixed layer height and classify clouds, Q. J. Roy. Meteorol. Soc.,144, 714, https://doi.org/10.1002/qj.3299, 2018.

Laborde, M., Schnaiter, M., Linke, C., Saathoff, H., Naumann, K.H., Möhler, O., Berlenz, S., Wagner, U., Taylor, J. W., Liu, D., Flynn, M., Allan, J. D., Coe, H., Heimerl, K., Dahlkötter, F., Weinzierl, B., Wollny, A. G., Zanatta, M., Cozic, J., Laj, P., Hitzenberger, R., Schwarz, J. P., and Gysel, M.: Single Particle Soot Photometer intercomparison at the AIDA chamber, Atmos. Meas. Tech., 5, 3077-3097, https://doi.org/10.5194/amt-5-30772012, 2012.

Laborde, M., Crippa, M., Tritscher, T., Jurányi, Z., Decarlo, P. F., Temime-Roussel, B., Marchand, N., Eckhardt, S., Stohl, A., Baltensperger, U., Prévôt, A. S. H., Weingartner, E., and Gysel, M.: Black carbon physical properties and mixing state in the European megacity Paris, Atmos. Chem. Phys., 13, 5831-5856, https://doi.org/10.5194/acp-13-5831-2013, 2013.

Li, B., Gasser, T., Ciais, P., Piao, S., Tao, S., Balkanski, Y., Hauglustaine, D., Boisier, J.-P., Chen, Z., and Huang, M.: The contribution of China's emissions to global climate forcing, Nature, 531, 357-361, 2016.

Li, M., Zhang, Q., Kurokawa, J.-I., Woo, J.-H., He, K., Lu, Z., Ohara, T., Song, Y., Streets, D. G., Carmichael, G. R., Cheng, Y., Hong, C., Huo, H., Jiang, X., Kang, S., Liu, F., Su, H., and Zheng, B.: MIX: a mosaic Asian anthropogenic emission inventory under the international collaboration framework of the MICS-Asia and HTAP, Atmos. Chem. Phys., 17, 935-963, https://doi.org/10.5194/acp-17-935-2017, 2017.

Liu, D., Flynn, M., Gysel, M., Targino, A., Crawford, I., Bower, K., Choularton, T., Jurányi, Z., Steinbacher, M., Hüglin, C., Curtius, J., Kampus, M., Petzold, A., Weingartner, E., Baltensperger, U., and Coe, H.: Single particle characterization of black carbon aerosols at a tropospheric alpine site in Switzerland, Atmos. Chem. Phys., 10, 7389-7407, https://doi.org/10.5194/acp10-7389-2010, 2010.

Liu, D., Allan, J., Corris, B., Flynn, M., Andrews, E., Ogren, J., Beswick, K., Bower, K., Burgess, R., Choularton, T., Dorsey, J., Morgan, W., Williams, P. I., and Coe, H.: Carbonaceous aerosols contributed by traffic and solid fuel burning at a polluted rural site in Northwestern England, Atmos. Chem. Phys., 11, 1603-1619, https://doi.org/10.5194/acp-11-1603-2011, 2011.

Liu, D., Li, J., Zhang, Y., Xu, Y., Liu, X., Ding, P., Shen, C., Chen, Y., Tian, C., and Zhang, G.: The use of levoglucosan and radiocarbon for source apportionment of $\mathrm{PM}_{2.5}$ carbonaceous aerosols at a background site in East China, Environ. Sci. Technol., 47, 10454-10461, 2013.

Liu, D., Allan, J. D., Young, D. E., Coe, H., Beddows, D., Fleming, Z. L., Flynn, M. J., Gallagher, M. W., Harrison, R. M., Lee, J.,
Prevot, A. S. H., Taylor, J. W., Yin, J., Williams, P. I., and Zotter, P.: Size distribution, mixing state and source apportionment of black carbon aerosol in London during wintertime, Atmos. Chem. Phys., 14, 10061-10084, https://doi.org/10.5194/acp-1410061-2014, 2014.

Liu, D., Taylor, J. W., Young, D. E., Flynn, M. J., Coe, H., and Allan, J. D.: The effect of complex black carbon microphysics on the determination of the optical properties of brown carbon, Geophys. Res. Lett., 42, 613-619, 2015.

Liu, D., Whitehead, J., Alfarra, M. R., Reyes-Villegas, E., Spracklen, D. V., Reddington, C. L., Kong, S., Williams, P. I., Ting, Y.-C., Haslett, S., Taylor, J. W., Flynn, M. J., Morgan, W. T., McFiggans, G., Coe, H., and Allan, J. D.: Black-carbon absorption enhancement in the atmosphere determined by particle mixing state, Nat. Geosci., 10, 184-188, https://doi.org/10.1038/ngeo2901, 2017.

Liu, D., Taylor, J. W., Crosier, J., Marsden, N., Bower, K. N., Lloyd, G., Ryder, C. L., Brooke, J. K., Cotton, R., Marenco, F., Blyth, A., Cui, Z., Estelles, V., Gallagher, M., Coe, H., and Choularton, T. W.: Aircraft and ground measurements of dust aerosols over the west African coast in summer 2015 during ICE-D and AER-D, Atmos. Chem. Phys., 18, 3817-3838, https://doi.org/10.5194/acp-18-3817-2018, 2018.

McMeeking, G. R., Hamburger, T., Liu, D., Flynn, M., Morgan, W. T., Northway, M., Highwood, E. J., Krejci, R., Allan, J. D., Minikin, A., and Coe, H.: Black carbon measurements in the boundary layer over western and northern Europe, Atmos. Chem. Phys., 10, 9393-9414, https://doi.org/10.5194/acp10-9393-2010, 2010.

Moteki, N., Kondo, Y., and Nakamura, S.-I.: Method to measure refractive indices of small nonspherical particles: Application to black carbon particles, J. Aerosol Sci., 41, 513-521, 2010.

Onasch, T., Trimborn, A., Fortner, E., Jayne, J., Kok, G., Williams, L., Davidovits, P., and Worsnop, D.: Soot particle aerosol mass spectrometer: development, validation, and initial application, Aerosol Sci. Technol., 46, 804-817, 2012a.

Onasch, T. B., Trimborn, A., Fortner, E. C., Jayne, J. T., Kok, G. L., Williams, L. R., Davidovits, P., and Worsnop, D. R.: Soot particle aerosol mass spectrometer: Development, validation, and initial application, Aerosol Sci. Technol., 46, 804-817, https://doi.org/10.1080/02786826.2012.663948, 2012b.

Paatero, P. and Tapper, U.: Positive matrix factorization: A non-negative factor model with optimal utilization of error estimates of data values, Environmetrics, 5, 111-126, https://doi.org/10.1002/env.3170050203, 1994.

Pratsinis, S. E.: Simultaneous nucleation, condensation, and coagulation in aerosol reactors, J. Colloid Interf. Sci., 124, 416-427, 1988.

Puxbaum, H., Caseiro, A., Sánchez-Ochoa, A., Kasper-Giebl, A., Claeys, M., Gelencsér, A., Legrand, M., Preunkert, S., and Pio, C.: Levoglucosan levels at background sites in Europe for assessing the impact of biomass combustion on the European aerosol background, J. Geophys. Res.-Atmos., 112, D23S05, https://doi.org/10.1029/2006jd008114, 2007.

Ramanathan, V. and Carmichael, G.: Global and regional climate changes due to black carbon, Nat. Geosci., 1, 221-227, 2008.

Riemer, N., West, M., Zaveri, R. A., and Easter, R. C.: Simulating the evolution of soot mixing state with a particle- 
resolved aerosol model, J. Geophys. Res.-Atmos., 114, D09202, https://doi.org/10.1029/2008JD011073, 2009.

Sandradewi, J., Prévôt, A. S., Szidat, S., Perron, N., Alfarra, M. R., Lanz, V. A., Weingartner, E., and Baltensperger, U.: Using aerosol light absorption measurements for the quantitative determination of wood burning and traffic emission contributions to particulate matter, Environ. Sci. Technol., 42, 3316-3323, 2008.

Schwarz, J., Gao, R., Spackman, J., Watts, L., Thomson, D., Fahey, D., Ryerson, T., Peischl, J., Holloway, J., and Trainer, M.: Measurement of the mixing state, mass, and optical size of individual black carbon particles in urban and biomass burning emissions, Geophys. Res. Lett., 35, L13810, https://doi.org/10.1029/2008GL033968, 2008.

Selimovic, V., Yokelson, R. J., Warneke, C., Roberts, J. M., de Gouw, J., Reardon, J., and Griffith, D. W. T.: Aerosol optical properties and trace gas emissions by PAX and OP-FTIR for laboratory-simulated western US wildfires during FIREX, Atmos. Chem. Phys., 18, 2929-2948, https://doi.org/10.5194/acp18-2929-2018, 2018.

Sun, H., Biedermann, L., and Bond, T. C.: Color of brown carbon: A model for ultraviolet and visible light absorption by organic carbon aerosol, Geophys. Res. Lett., 34, L17813, https://doi.org/10.1029/2007GL029797, 2007.

Sun, Y. L., Wang, Z. F., Du, W., Zhang, Q., Wang, Q. Q., Fu, P. Q., Pan, X. L., Li, J., Jayne, J., and Worsnop, D. R.: Longterm real-time measurements of aerosol particle composition in Beijing, China: seasonal variations, meteorological effects, and source analysis, Atmos. Chem. Phys., 15, 10149-10165, https://doi.org/10.5194/acp-15-10149-2015, 2015.

Sun, Y., Du, W., Fu, P., Wang, Q., Li, J., Ge, X., Zhang, Q., Zhu, C., Ren, L., Xu, W., Zhao, J., Han, T., Worsnop, D. R., and Wang, Z.: Primary and secondary aerosols in Beijing in winter: sources, variations and processes, Atmos. Chem. Phys., 16, 8309-8329, https://doi.org/10.5194/acp-16-8309-2016, 2016a.

Sun, Y., Wang, Z., Wild, O., Xu, W., Chen, C., Fu, P., Du, W., Zhou, L., Zhang, Q., Han, T., Wang, Q., Pan, X., Zheng, H., Li, J., Guo, X., Liu, J., and Worsnop, D. R.: "APEC Blue": Secondary Aerosol Reductions from Emission Controls in Beijing, Sci. Rep, 6, 20668, https://doi.org/10.1038/srep20668, 2016b.

Tao, M., Chen, L., Su, L., and Tao, J.: Satellite observation of regional haze pollution over the North China Plain, J. Geophys. Res.-Atmos., 117, D12203, https://doi.org/10.1029/2012jd017915, 2012.

Taylor, J. W., Allan, J. D., Liu, D., Flynn, M., Weber, R., Zhang, X., Lefer, B. L., Grossberg, N., Flynn, J., and Coe, H.: Assessment of the sensitivity of core/shell parameters derived using the singleparticle soot photometer to density and refractive index, Atmos. Meas. Tech., 8, 1701-1718, https://doi.org/10.5194/amt-8-17012015, 2015.

Viana, M., Kuhlbusch, T., Querol, X., Alastuey, A., Harrison, R., Hopke, P., Winiwarter, W., Vallius, M., Szidat, S., and Prevot, A.: Source apportionment of particulate matter in Europe: a review of methods and results, J. Aerosol Sci., 39, 827-849, 2008.

Wang, J., Zhang, Q., Chen, M., Collier, S., Zhou, S., Ge, X., $\mathrm{Xu}$, J., Shi, J., Xie, C., Hu, J., Ge, S., Sun, Y., and Coe, H.: First Chemical Characterization of Refractory Black Carbon Aerosols and Associated Coatings over the Tibetan Plateau (4730 m a.s.1), Environ. Sci. Technol., 51, 14072-14082, https://doi.org/10.1021/acs.est.7b03973, 2017.
Wang, J., Liu, D., Ge, X., Wu, Y., Shen, F., Chen, M., Zhao, J., Xie, C., Wang, Q., Xu, W., Zhang, J., Hu, J., Allan, J., Joshi, R., Fu, P., Coe, H., and Sun, Y.: Characterization of black carboncontaining fine particles in Beijing during wintertime, Atmos. Chem. Phys., 19, 447-458, https://doi.org/10.5194/acp-19-4472019, 2019.

Wang, Q., Huang, R. J., Cao, J., Han, Y., Wang, G., Li, G., Wang, Y., Dai, W., Zhang, R., and Zhou, Y.: Mixing State of Black Carbon Aerosol in a Heavily Polluted Urban Area of China: Implications for Light Absorption Enhancement, Aerosol Sci. Tech., 48, 689697, https://doi.org/10.1080/02786826.2014.917758, 2014.

Wang, Q., Huang, R. J., Zhao, Z., Cao, J., Ni, H., Tie, X., Zhao, S., $\mathrm{Su}, \mathrm{X}$., Han, Y., and Shen, Z.: Physicochemical characteristics of black carbon aerosol and its radiative impact in a polluted urban area of China, J. Geophys. Res.-Atmos., 121, 12505-12519, https://doi.org/10.1002/2016JD024748, 2016.

Wang, S. and Hao, J.: Air quality management in China: Issues, challenges, and options, J. Environ. Sci., 24, 2-13, 2012.

Wang, X., Westerdahl, D., Chen, L. C., Wu, Y., Hao, J., Pan, X., Guo, X., and Zhang, K. M.: Evaluating the air quality impacts of the 2008 Beijing Olympic Games: On-road emission factors and black carbon profiles, Atmos. Environ., 43, 4535-4543, 2009.

Wu, Y., Cheng, T., Liu, D., Allan, J. D., Zheng, L., and Chen, H.: Light Absorption Enhancement of Black Carbon Aerosol Constrained by Particle Morphology, Environ. Sci. Technol., 52, 6912-6919, https://doi.org/10.1021/acs.est.8b00636, 2018.

$\mathrm{Xu}, \mathrm{S} ., \mathrm{Liu}, \mathrm{W}$. , and Tao, S.: Emission of polycyclic aromatic hydrocarbons in China, Environ. Sci. Technol., 40, 702-708, 2006.

$\mathrm{Xu}, \mathrm{X}$. , Gao, J., Gao, J., and Chen, Y.: Air pollution and daily mortality in residential areas of Beijing, China, Arch. Environ. Health: An Int. J., 49, 216-222, 1994.

Yan, C., Zheng, M., Sullivan, A. P., Shen, G., Chen, Y., Wang, S., Zhao, B., Cai, S., Desyaterik, Y., and Li, X.: Residential Coal Combustion as a Source of Levoglucosan in China, Environ. Sci. Technol., 52, 1665-1674, 2018.

Yang, J., McBride, J., Zhou, J., and Sun, Z.: The urban forest in Beijing and its role in air pollution reduction, Urban Forest. Urban Green., 3, 65-78, 2005.

Yang, Y., Xu, X., Zhang, Y., Zheng, S., Wang, L., Liu, D., Gustave, W., Jiang, L., Hua, Y., Du, S., and Tang, L.: Seasonal size distribution and mixing state of black carbon aerosols in a polluted urban environment of the Yangtze River Delta region, China, Sci. Total Environ., 654, 300-310, https://doi.org/10.1016/j.scitotenv.2018.11.087, 2018.

Zhang, Q., Quan, J., Tie, X., Li, X., Liu, Q., Gao, Y., and Zhao, D.: Effects of meteorology and secondary particle formation on visibility during heavy haze events in Beijing, China, Sci. Total Environ., 502, 578-584, 2015.

Zhang, R., Jing, J., Tao, J., Hsu, S.-C., Wang, G., Cao, J., Lee, C. S. L., Zhu, L., Chen, Z., Zhao, Y., and Shen, Z.: Chemical characterization and source apportionment of $\mathrm{PM}_{2.5}$ in Beijing: seasonal perspective, Atmos. Chem. Phys., 13, 7053-7074, https://doi.org/10.5194/acp-13-7053-2013, 2013.

Zhang, X., Mao, M., Yin, Y., and Wang, B.: Numerical Investigation on Absorption Enhancement of Black Carbon Aerosols Partially Coated With Nonabsorbing Organics, J. Geophys. Res.-Atmos., 123, 1297-1308, https://doi.org/10.1002/2017jd027833, 2018.

Zhang, Y. L., Perron, N., Ciobanu, V. G., Zotter, P., Minguillón, M. C., Wacker, L., Prévôt, A. S. H., Baltensperger, U., 
and Szidat, S.: On the isolation of OC and EC and the optimal strategy of radiocarbon-based source apportionment of carbonaceous aerosols, Atmos. Chem. Phys., 12, 10841-10856, https://doi.org/10.5194/acp-12-10841-2012, 2012.

Zhang, Y., Ren, H., Sun, Y., Cao, F., Chang, Y., Liu, S., Lee, X., Agrios, K., Kawamura, K., Liu, D., Ren, L., Du, W., Wang, Z., Prevot, A. S. H., Szidat, S., and Fu, P.: High Contribution of Nonfossil Sources to Submicrometer Organic Aerosols in Beijing, China, Environ. Sci. Technol., 51, 7842-7852, https://doi.org/10.1021/acs.est.7b01517, 2017.

Zhang, Y., Yuan, Q., Huang, D., Kong, S., Zhang, J., Wang, X., Lu, C., Shi, Z., Zhang, X., and Sun, Y.: Direct observations of fine primary particles from residential coal burning: insights into their morphology, composition, and hygroscopicity, J. Geophys. Res.-Atmos., 123, 12964-12979, 2018a.
Zhang, Y., Zhang, Q., Cheng, Y., Su, H., Li, H., Li, M., Zhang, X., Ding, A., and He, K.: Amplification of light absorption of black carbon associated with air pollution, Atmos. Chem. Phys., 18, 9879-9896, https://doi.org/10.5194/acp-18-9879-2018, 2018b.

Zhao, B., Wang, S., Wang, J., Fu, J. S., Liu, T., Xu, J., Fu, X., and Hao, J.: Impact of national $\mathrm{NO}_{x}$ and $\mathrm{SO}_{2}$ control policies on particulate matter pollution in China, Atmos. Environ., 77, 453463, 2013.

Zotter, P., Herich, H., Gysel, M., El-Haddad, I., Zhang, Y., Mocnik, G., Hüglin, C., Baltensperger, U., Szidat, S., and Prévôt, A. S. H.: Evaluation of the absorption Ångström exponents for traffic and wood burning in the Aethalometer-based source apportionment using radiocarbon measurements of ambient aerosol, Atmos. Chem. Phys., 17, 4229-4249, https://doi.org/10.5194/acp17-4229-2017, 2017. 